\title{
DIGITALCOMMONS
}

@WAYNESTATE-

Wayne State University

7-1-1999

\section{Questioning Traditional Antitrust Presumptions: Price and Non-Price Competition in Hospital Markets}

Peter J. Hammer

University of Michigan, phammer@wayne.edu

\section{Recommended Citation}

Peter J. Hammer, Questioning Traditional Antitrust Presumptions: Price and Non-Price Competition in Hospital Markets, 32 U. Mich. J.L. Reform 727 (1999).

Available at: https://digitalcommons.wayne.edu/lawfrp/246 


\author{
Peter J. Hammer*
}

\begin{abstract}
Hospital mergers challenge basic assumptions about the effects of market power in the health care industry. Antitrust courts have struggled with claims that hospital mergers may in fact reduce costs and lower prices. This Article assesses the validity of these economic claims in the context of an industry that has undergone radical transformations in recent years. The Article also explores how such arguments should be treated as a matter of antitrust doctrine in an area of the law that relies heavily on market share presumptions and rule-based decision making. The Article contends that courts should employ a total welfare standard of merger review and attempt to directly assess the value of non-price competition. The Article further argues that courts should avoid focusing exclusively on consumer surplus and should reject hospital overtures to entertain a variety of non-economic justifications for merger.
\end{abstract}

\title{
INTRODUCTION
}

Hospital mergers raise challenges regarding the effects of market power in the health care industry and the role of presumptions in antitrust law. The first challenge concerns the relationship between market power and health care costs. In the $1980 \mathrm{~s}$, a substantial body of empirical work was published, establishing a strong and consistent correlation between competition and medical expenses. ${ }^{1}$ These studies indicated that market power was

* Assistant Professor, University of Michigan Law School. B.S. 1986, B.A. 1986, Gonzaga University; J.D. 1990, University of Michigan Law School; Ph.D. 1993, University of Michigan.

1. See, e.g., Monica Noether, federal Trade Commission, Competition Among Hospitals (1987) [hereinafter NoEther, Competition] (examining the effect of competition on aggregate hospital expenses taken from 1977-78 Medicare Cost Reports and finding that competition is associated with higher medical costs); Monica Noether, Competition Among Hospitals, 7 J. Health Econ. 259 (1988) (same); Philip J. Held \& Mark V. Pauly, Competition and Efficiency in the End Stage Renal Disease Program, 2 J. HEALTh Econ. 95 (1983) (examining the effects of competition in the provision of end stage renal dialysis using 1975 data and finding that market power is associated with higher profits, which the authors attribute to the lower costs associated with reduced non-price competition); Paul L. Joskow, The Effects of Competition and Regulation on Hospital Bed Supply and the Reservation Quality of the Hospital, 11 BELL J. ECON. 421 (1980) (examining the effects of competition on a measure of hospital capacity using 1979 data and finding that hospital competition is associated with increased capacity, which is viewed as a proxy for non-price competition); James C. 
frequently associated with lower medical costs. The second challenge concerns the relationship between market power and the prices of hospital services. Researchers such as William Lynk contend that hospital mergers, particularly among nonprofit hospitals, may produce lower post-merger prices. ${ }^{2}$ On the surface, these findings contradict the predictions of standard economic theory-that competition should lead to lower prices and greater productive efficiency-and raise legitimate questions about the rigid application of traditional presumptions to hospital mergers. ${ }^{3}$ Antitrust

Robinson \& Harold S. Luft, Competition and the Cost of Hospital Care, 1972 to 1982, 257 JAMA 3241 (1987) [hereinafter Robinson \& Luft, Competition] (employing 1982 data and modified measures of market power and confirming their earlier findings that competition is associated with higher hospital expenses); James C. Robinson \& Harold S. Luft, The Impact of Hospital Market Structure on Patient Volume, Average Length of Stay, and the Cost of Care, 4 J. HEALTH ECON. 333 (1985) [hereinafter Robinson \& Luft, Hospital Market Structure] (examining effects of competition on hospital costs using 1972 data and finding that competition is associated with higher hospital costs measured on a per-patient day and per-admission basis); George W. Wilson \& Joseph M. Jadlow, Competition, Profit Incentives, and Technical Efficiency in the Provision of Nuclear Medicine Services, 13 BELL J. ECON. 472 (1982) (estimating the effect of competition on productive efficiency in the provision of nuclear medicine using 1973 data and finding that competition is associated with productive inefficiency, a finding attributed to more intense non-price competition). For reviews of this literature, see Frederic J. Entin et al., Hospital Collaboration: The Need for an Appropriate Antitrust Policy, 29 WAKE FoREST L. REV. 107, 153-67 (1994); Paul A. Pautler \& Michael G. Vita, Hospital Market Structure, Hospital Competition and Consumer Welfare: What Can the Evidence Tell Us?, $10 \mathrm{~J}$. Contemp. Health L. \& PoL'y 117, 123-29 (1994); Peter J. Hammer, Mergers, Market Power and Competition: An Economic and Legal Evaluation of Hospital Mergers 22-27 (1993) (unpublished Ph.D. dissertation, University of Michigan) (on file with author) [hereinafter Hammer, Mergers, Market Power and Competition]. Many advocates of hospital mergers have been quick to label these lower costs as "efficiencies." As will be seen, such a label is premature and fails to acknowledge the important role of non-price competition in hospital markets.

2. See William J. Lynk, Nonprofit Hospital Mergers and the Exercise of Market Power, 38 J.L. \& ECON. 437, 449-52 (1995) (examining the effect of market power and nonprofit status on hospital pricing employing 1989 data from California and finding (1) that nonprofit hospitals charge lower prices than for-profit hospitals, and (2) that the merger of two non-profit hospitals may actually lower prices). While the connection between competition and higher medical costs reflects a near consensus position of the literature in the 1980s, the hospitals' price claims are much more controversial and have been challenged by other researchers. See David Dranove \& Richard Ludwick, Competition and Pricing by Nonprofit Hospitals: A Reassessment of Lynk's Analysis, 18 J. HeALTH Econ. 87, 97 (1999) (critically evaluating Lynk's 1995 study, specifying a different model using the same underlying data, and concluding that nonprofit mergers are not associated with lower prices); Emmett B. Keeler et al., The Changing Effects of Competition on Nonprofit and For-Profit Hospital Pricing Behavior, $18 \mathrm{~J}$. HeALTH ECON. 69, 78-80 (1999) (examining the effects of market power on hospital prices using California data from 1986-94 and finding that market power is associated with higher prices regardless of for- or nonprofit status, and that hospital markets became increasingly pricecompetitive over the period being examined). But see William J. Lynk \& Lynette R. Neumann, Price and Profit, 18 J. Health Econ. 99, 110 (1999) (responding to various criticisms of Lynk's 1995 study and defending his testimony in the Butterworth merger case).

3. The presumption that market power produces anticompetitive effects constitutes the galvanizing force behind section 7 of the Clayton Act, which prohibits mergers and acquisitions where the effect "may be substantially to lessen competition, or to tend to create a 
lawyers and commentators almost immediately recognized the difficulties this evidence raised for antitrust policy. ${ }^{4}$ The intervening years have witnessed confusion in the case law, as courts have struggled with these conflicting claims and have come to conclusions that are often difficult to reconcile with traditional doctrine. ${ }^{5}$

This Article has two objectives. The first objective is to untangle the complicated web of issues surrounding hospital competition and to provide a framework in which lawyers and judges can better understand the empirical research and its implications for merger analysis. The second objective is to use the provocative issues raised by hospital mergers as a vehicle to explore more generally the role that presumptions play in merger analysis. The economics of hospital mergers directly challenge core antitrust beliefs: the belief that competition will efficiently allocate resources along price and non-price dimensions, and the belief that competition will lower prices. The resolution of these issues will have implications for antitrust law that extend far beyond the health care field.

monopoly." 15 U.S.C. $\$ 18$ (1994). In light of this presumption, judicial decision making follows a fairly settled pattern: courts define economic markets, calculate concentration ratios, infer the existence of market power from concentration ratios that are "sufficiently high" and, finally, presume the existence of anticompetitive effects from a finding of market power. See Herbert Hovenkamp, Federal antitrust Policy: The Law of Competition AND ITS PRACTICE $\$ 12.1 \mathrm{a}$, at 444-45, \$ 12.3d, at 464-66 (1994) (discussing the role of market-share rules and presumptions in antitrust merger analysis). Judicial reliance upon presumptions can be an effective means of decision making, but presumptions will yield defensible results only if appropriate economic theories and empirical evidence support the legal inferences.

4. See, e.g., William G. Kopit \& Robert W. McCann, Toward a Definitive Antitrust Standard for Nonprofit Hospital Mergers, 13 J. HeAlTH PoL. PoL'y \& L. 635, 645, 656 (1988) (noting the results of economic research and advocating against the rigid application of traditional antitrust standards to nonprofit hospital mergers); Carl J. Schramm \& Steven C. Renn, Hospital Mergers, Market Concentration and the Herfindahl-Hirschman Index, 33 EмоRy L. J. 869, 884 (1984) (noting the results of economic research and advocating against the application of standard market-share rules to hospital mergers). The vigor with which critics challenge the rigid application of antitrust rules to hospital mergers has not diminished over time. See William G. Kopit, Can the Nonprofit Status of the Merging Facilities Change the Proper Analysis of a Hospital Merger Under the Antitrust Laws?, in ANTITRuSt in THE HealthCare Field 19-22 (American Health Lawyers Association ed., 1999) (discussing the economic testimony presented in Butterworth and calling for greater recognition of nonprofit status in assessing the competitive effects of hospital mergers); William G. Kopit \& Tanya B. Vanderbilt, Unique Issues in the Analysis of Nonprofit Hospital Mergers, 35 WASHBURN L.J. 254, 256-57 (1996) (citing the absence of a correlation between concentration and higher hospital prices and calling upon antitrust courts to accommodate the unique aspects of nonprofit hospital mergers).

5. Two district courts, for example, have openly challenged the usually unassailable belief that market power leads to higher prices. See FTC v. Butterworth Health Corp., 946 F. Supp. 1285, 1295-96 (W.D. Mich. 1996), affd without op., 121 F.3d 708, reported in full, 1997-2 Trade Cas. (CCH) I 71,863 (6th Cir. 1997); United States v. Carilion Health System, 707 F. Supp. 840, 846 (W.D. Va.), affd without op., 892 F.2d 1042, reported in full, 1989 WL 157282 (4th Cir, 1989) 
Part I examines hospital markets and contrasts the effects of competition in what I term the "Old" and the "Emerging" Regimes. In the Old Regime, hospitals compete almost exclusively along non-price dimensions. Not surprisingly, competition in this setting is associated with higher levels of non-price services, higher costs, and not necessarily lower prices. The institutional structures of the Emerging Regime, however, facilitate greater price-based competition. In such an environment, one would expect an allocatively more efficient balance between price and non-price competition. Antitrust analysis is complicated by the fact that enforcement agencies are most likely to challenge mergers in markets that are still mired in the Old Regime or that are on the cusp of transition.

Part II explores the role of presumptions in merger analysis. Antitrust courts and the enforcement agencies rely heavily on rulebased decision making. Some aspects of these presumptions are rebuttable, other aspects are not. The basic beliefs that competitive markets are allocatively efficient, and that market power is bad, cast a long shadow over these rules. Defendants in hospital merger cases, however, argue that market power may be desirable. These claims test the boundaries of the types of arguments judges are willing to entertain. Part II examines factors courts have identified for use in rebutting market-share presumptions, addresses whether the alleged benefits of market power can be balanced against acknowledged anticompetitive effects, and contrasts a framework of intra-economic balancing with a framework of extra-economic balancing.

Part III examines how courts and the Federal Trade Commission (FTC) have responded to hospitals' non-price competition claims. It is conceivable that competition in the Old Regime misallocates resources. Whether mergers should be used to effectuate a different outcome, however, raises controversial issues about when, if ever, antitrust courts should question the efficiency of markets. The fact that there are clear winners and losers in the suppression of non-price competition further complicates the analysis. Restricting non-price competition via merger will increase producer surplus (profits) and decrease consumer surplus. Part III criticizes the courts and the FTC for failing to recognize and balance these conflicting effects and explores how the problem might be resolved under a total welfare standard of merger review.

Part IV explores how courts and the FTC have responded to hospitals' price claims. Disputes on the price front are hotly contested both as a matter of economic theory and empirical 
evidence. ${ }^{6}$ The FTC has flatly rejected the hospitals' price-related contentions, but some district courts have been more receptive. The Butterworth ${ }^{7}$ district court, for example, was persuaded that market power controlled by nonprofit hospitals was not associated with higher prices; $^{8}$ that the community-based structure of the merged hospitals' board would constrain any anticompetitive effects;" and that the hospitals had signed a "Community Commitment Letter" promising not to increase prices. ${ }^{10}$ As the Butterworth factors suggest, the hospitals' price claims can be used both as a forum to air economic arguments in favor of increased market power, and as a shield to potentially mask consideration of a variety of extra-economic objectives.

Part V examines the lessons from the hospital merger cases and explores the extent to which the presumption that market power is undesirable should be rebuttable. A conservative approach would maintain a strong and irrefutable presumption concerning the effects of market power, but would invoke this presumption in a

6. In what has been called "Posner's lament," Judge Richard Posner terms "regrettable" the absence of solid empirical evidence to guide judges in evaluating the competitive implications of hospital mergers:

It is regrettable that antitrust cases are decided of the basis of theoretical guesses as to what particular market-structure characteristics portend for competition, but to place on the government an insuperable burden of proof is not the answer. We would like to see more effort put into studying the actual effect of concentration on price in the hospital industry as in other industries. If the government is right in these cases, then, other things being equal, hospital prices should be higher in markets with fewer hospitals. This is a studiable hypothesis, by modern methods of multivariate statistical analysis, and some studies have been conducted correlating prices and concentration in the hospital industry. Unfortunately, this literature is at an early and inconclusive stage, and the government is not required to await the maturation of the relevant scholarship in order to establish a prima facie case.

United States v. Rockford Memorial Corp., 898 F.2d 1278, 1286 (7th Cir. 1990) (citations omitted).

While everyone can appreciate the importance of a better understanding of the empirical effects of market structure in the health care industry, Posner fails to address whether and how courts should consider such industry-specific information in light of antitrust laws' categorical rules and market-share presumptions. For a discussion of the reaction of economists to Posner's characterization of the industrial organization and health care literature see Harold Demsetz et al., Policy Adequacy of the Empirical Concentration-Price Studies: The Pasner Lament, 22 Antrtrust L. \& Econ. Rev. 19 (1990); Paul J. Feldstein et al., Concentration and Price in the Hospital Industry: Prices Are Lower in Competitive Markets, 22 ANTITRUST L. \& Econ. REv. 55 (1990).

7. FTC v. Butterworth Health Corp., 946 F. Supp. 1285, 1295-96 (W.D. Mich. 1996), affd without op., 121 F.3d 708, reported in full, 1997-2 Trade Cas. (CCH) I 71,863 (6th Cir. 1997).

8. See id. at $1295-96$.

9. See id. at $1296-97$.

10. See id. at 1298 . 
more self-conscious manner to better channel disputes out of the courts and into the legislative process. The FTC and some district courts have followed this model and have relied heavily upon market-share rules to guide their decisions. A more progressive alternative would treat the effect of market power as a contestable issue of fact. This approach would permit courts to balance the potential economic benefits of market power against acknowledged anticompetitive consequences. To do so effectively, however, courts would have to develop a better analytic framework for assessing the total welfare effects of merger. Unfortunately, the courts that have accepted hospital arguments in favor of increased market power have done so without engaging in the necessary welfare analysis and without maintaining a reasoned distinction between economic and extra-economic arguments in favor of merger.

\section{Hospital Competition: The Old AND EMERGING ReGIMES}

This Part presents a simplified description of the structure and operation of health care markets with the goal of better understanding hospital competition." Assessing hospital mergers presents a dual challenge. Not only are medical markets different from the types of manufacturing-based markets that have traditionally been the subject of antitrust scrutiny, but hospital markets are also frequently different from one another. In the last fifteen years, the health care industry has undergone fundamental changes, but changes across markets have not been uniform. As a

11. For a discussion of the structure and organization of health care markets and institutions, see generally Paul Starr, The Social Transformation of American Medicine (1982), and Rosemary Stevens, In Sickness and in Wealth (1989). For discussions of health care economics, see generally Kenneth J. Arrow, Uncertainty and the Welfare Economics of Medical Care, 53 Am. Econ. Rev. 941 (1963); Joseph P. Newhouse, The Erosion of the Medical Marketplace, 2 Advances in Health Econ. \& Health Services Res. 1 (1981); Mark V. Pauly, Is Medical Care Different? in Competition in the Health Care Sector: Past, PresENT AND FUTURE 19 (Warren Greenberg ed., 1978); Mark V. Pauly, Is Medical Care Different?: Old Questions, New Answers, in Competition in the Health Care Sector: Ten Years Later 5 (Warren Greenberg ed., 1988). For a critical assessment and evaluation of health care markets, see generally Robert G. Evans, Going for the Gold: The Redistributive Agenda Behind Market-Based Health Care Reform, in Healthy Markets: The New Competition in Medical CARE 66 (Mark A. Peterson ed., 1998) [hereinafter Healthy Markets]; Martin Gaynor \& William B. Vogt, What Does Economics Have to Say About Health Policy Anyway? A Comment and Correction on Evans and Rice, in Healthy Markets, supra, at 110; Mark V. Pauly, Who Was That Straw Man Anyway? A Comment on Evans and Rice, in Healthy Markets, supra, at 104; Thomas Rice, Can Markets Give Us the Heallh System We Want?, in HeAlthy Markets, supra, at 27. 
result, the dynamics of hospital competition in one market may be very different from the dynamics of competition in another.

While hospitals are collectively constrained by market demand, individual administrators are more concerned with the determinants of hospital-specific demand. Actions that have a negligible impact on market demand may have a significant effect on the demand for a particular hospital's services. ${ }^{12}$ The factors that influence hospital-specific demand include: price, the actual quality of the services, the perceived quality of the services, contracts with insurance companies and other third-party payors, and physician affiliation. To the extent hospitals can improve profitability by altering any of these factors, given appropriate assumptions about competitor reactions, they will "compete" along all of these dimensions.

The effects of price on hospital-specific demand are straightforward. Higher prices should decrease the quantity of services demanded from a given supplier. Conversely, lower prices should stimulate demand. The relative importance of price as a competitive factor depends upon the price elasticity of hospital-specific demand (the relative sensitivity of changes in demand to proportionate changes in price). ${ }^{19}$ The price elasticity of hospital-specific demand will depend upon the extent of selective contracting by third-party payors, the extent to which physicians control patient decisions, and the types of consumer incentives used in prevailing insurance contracts.

Quality considerations play an important role in a patient's selection of a health care provider. Patients directly internalize the benefits of quality searches and quality-based decisions. The role of quality differentials in the selection among competing suppliers is even greater if insurance arrangements do not force patients to internalize some portion of the cost of making higher quality choices. As a result, a hospital that increases the quality of its

12. The distinction between market and firm-specific demand is important because the ability of firms to "steal" demand from competitors is the primary force motivating rentdissipating forms of non-price competition. See Held \& Pauly, supra note 1, at 100-03. From this perspective, the dynamics of hospital non-price rivalry are structurally similar to the rivalry characteristic of the price-regulated airline industry in the 1970s. The provision of non-price amenities by one airline probably had a negligible impact on the market demand for airline services, but it may have substantially increased the firm-specific demand of the airline in question, typically at the expense of its competitors. See generally Lawrence J. White, Quality Competition and Regulation: Evidence from the Airline Industry, in REgulating the Product (R.E. Caves \& M.J. Roberts eds., 1975); Lawrence J. White, Quality Variation When Prices Are Regulated, 3 Bell J. Econ. 425, 428-29 (1972).

13. See Robert Cooter \& Thomas Ulen, Law and Economics 29 (1988) (defining price elasticity of demand). 
services should enjoy increased firm-specific demand primarily at the expense of lower quality suppliers. To the extent that patients can accurately assess the quality of medical services, they respond to "actual" quality differentials. Under conditions of imperfect information, patients respond to "perceived" quality differentials. The latter are manifested in reputational assets that may or may not correspond to real quality improvements.

Institutional aspects of medical markets add two other considerations to the factors determining the level of hospital-specific demand. Frequently, patients do not make the ultimate selection of a hospital. Both third-party payors and physicians are potential sources of medical demand. If patients select hospitals implicitly through their choice of insurance, then the number of contracts a hospital has with third-party payors will influence its demand. Alternatively, if patients select hospitals implicitly through their choices of physicians, then the level of hospital demand will largely be determined by physician affiliation. Depending upon which regime is in place, hospitals have incentives to compete with each other for the loyalties of either physicians or third-party payors. Competition for third-party payors (large employers and insurance companies) is likely to take the form of price concessions (the Emerging Regime), while competition for physicians likely results in the provision of amenities that correspond to elements in physician utility functions (the Old Regime). ${ }^{14}$

The effect that hospital mergers have upon price and non-price competition will depend upon the prevailing institutional arrangements. As suggested, it is useful to distinguish the effects of merger in the "Old Regime" from the effects of merger in the "Emerging Regime." Prior to 1980, practically all hospital markets would have fallen within the Old Regime. Numerous reforms since that time, both private and public, have fundamentally changed the nature of hospital competition in most markets. Depending upon the scope of reforms, any particular hospital market may lie somewhere along a continuum between "Old" and fully "Emerged." The primary differences between these extremes concern the roles played by physicians and third-party payors. The following is a highly stylized description. In the Old Regime, third-party payors act in a passive fashion, observe a cost-based, fee-for-service system for determining reimbursement, and employ a community-wide standard

14. The institutional factors motivating non-price competition in the Old Regime have been widely discussed in the health care literature. See Joskow, supra note 1, at 431-33; Robinson \& Luft, Competition, supra note 1, at 3241-42; Robinson \& Luft, Hospital Market Structure, supra note 1, at 334-35; Wilson \& Jadlow, supra note 1, at 473 . 
to determine the reasonableness of hospital charges. As a result, hospital price competition is virtually non-existent and prices are implicitly set at the community level. ${ }^{15}$ In the Old Regime, physicians play an active role as "patient brokers," largely controlling a patient's selection of a hospital. Under these circumstances, non-price competition dominates hospital interaction as hospitals actively compete in terms of quality and physician affiliation.

The transition from the Old to the Emerging Regime began with increasing levels of activism on the part of third-party payors (typically large employers). Active payors negotiate directly with hospitals over the price and terms of patient treatment and enter into selective contracts, potentially excluding some health care providers entirely. Selective contracting allows third-party payors to deliver guaranteed demand to participating hospitals in return for price concessions. These contracts establish the important link between price and demand that is largely absent from the Old Regime, increasing the price elasticity of firm-specific demand. The physician's role as the patient's agent is exercised (if at all) within choice constraints established by third-party payors. Increasingly, the Emerging Regime also involves the combination of insurers, physicians, and hospitals into integrated providers of the financing and delivery of health care services. This phenomenon can involve a tiered process, beginning with loose contractual affiliations between physicians, hospitals, and insurance companies, and sometimes progressing towards complete integration of these functions within a single economic entity or firm. ${ }^{16}$ Today, it is reasonable to view the degree of managed care penetration into a given market as a proxy for assessing the vitality of the Old Regime and the strength of the Emerging Regime.

The Old and Emerging Regimes correspond to very different models of hospital competition. In the Old Regime, price competition is not a central concern and lower levels of economic concentration are not necessarily associated with lower hospital prices-unadjusted for differences in quality and other non-price

15. See Hammer, Mergers, Market Power and Competition, supra note 1, at 53-54.

16. The changes in health care markets reflect a fundamental redefinition of the types of economic transactions that take place at the market level and those that are carried out internally by a firm or business. As such, the transition from the Old to the Emerging Regime can be understood as a Coasian transformation of the nature of the firm. See R.H. Coase, The Nature of the Firm, 4 Economica 386, 390-98 (1937). For a discussion of changes in the health care markets based on a theory of the firm perspective and an examination of the implications that such changes have for antitrust reforms see Peter J. Hammer, Medical Antitrust Reform: Arrow, Coase and the Changing Structure of the Firm, in The Privatization of Health Care Reform (Gregg Bloche ed., forthcoming 2000) (on file with author) [hereinafter Hammer, Arrow, Coase and the Changing Structure of the Firm]. 
attributes. Numerous market failures in the medical industry mute the relationship between market power and price or, at a minimum, so narrow the range separating "monopoly" and "competitive" prices as to render the distinction statistically insignificant. For example, economist Monica Noether conducted a comprehensive cross-sectional examination of the effects of economic concentration using pricing data from 1977-78 Medicare Cost Reports. ${ }^{17}$ The coefficients of variables reflecting the effect of market power on hospital prices were not statistically significant. ${ }^{18}$ Rather than indicating that market power is not exercised in hospital markets, the study suggests that the institutional arrangements characteristic of the Old Regime so restrict price competition that traditional market power is not necessary to charge supracompetitive prices.

Restricting competition in one area, however, is like squeezing a balloon. In the absence of price competition, competition in the Old Regime occurs almost entirely in terms of non-price rivalry. ${ }^{19}$ Predictably, differences in market structure influence the nature and extent of this non-price competition. Monopolists are relatively immune from the need to compete along non-price dimensions. Consequently, expenditures on quality attributes, reputational assets, and physician loyalty are lower in concentrated hospital markets than in markets with a significant number of competitors. Again, this contention is consistent with the empirical evidence. A review of studies employing pre-1983 data (data reflecting conditions largely characteristic of the Old Regime) reveals a strong and consistent negative relationship between measures of hospital cost and levels of economic concentration. ${ }^{20}$ Competitive pressures do not disappear; instead they are channeled along non-price dimensions. This facet of traditional health care markets has a number of implications for the application of antitrust laws to hospital mergers and the relationship between market power and price in the Old Regime-implications that have largely been neglected or misunderstood.

17. See Noether, Competition, supra note 1 , at 43.

18. See id. at 55 .

19. George Stigler was among the first to formally model and discuss the symmetries between price and non-price competition. See George J. Stigler, Price and Non-Price Competition, 76 J. Pol. Econ. 149, 150-52 (1968); see also Peter J. Hammer, Price and Quality Competition in Health Care Markets: The Comparative Institutional Case Against an Antitrust Exemption for Medical Self Regulatory Entities, in Achieving Quality in MaNaGed CaRe: The Role of LAw 123, 131 (John D. Blum ed., 1997) [hereinafter Hammer, Price and Quality Competition] (applying Stigler's analysis to medical markets).

20. See sources cited supra note 1 . 
The important economic question in the Old Regime is whether the degree of non-price competition that takes place is socially desirable. It is plausible to describe hospital non-price competition in terms of a rent dissipating story-the so-called "medical arms race." If this is the case, then society might be better off with lower aggregate levels of non-price competition. The issue is complicated by the fact that there are clear distributional winners and losers when market power is used to decrease non-price competition: producer surplus (hospital profit) is increased, while consumer surplus is decreased. ${ }^{22}$ This leads to a difficult question for antitrust law. Can (or should) courts consider arguments in favor of merger that are premised on the alleged benefits of market power, such as systematic reductions in wasteful non-price competition? If such arguments are entertained, should courts employ a total welfare standard or a consumer surplus standard of merger review in deciding which increases in market power to permit and which to prohibit? ? $^{23}$

These same issues are not raised in the Emerging Regime. While some courts and commentators have purported to find lower hospital prices in markets with higher levels of economic concentration ${ }^{24}$ the Emerging Regime sustains the prospect of active price competition between hospitals. ${ }^{25}$ Moreover, in markets where meaningful price competition takes place in tandem with active non-price competition, the rent dissipating story characteristic of the Old Regime is substantially less credible. The levels of market investment in non-price attributes in the Emerging Regime are more likely to reflect actual consumer preferences (or at least

21. See David Dranove et al., Is Hospital Competition Wasteful?, 23 RAND J. Econ. 247, 257-60 (1992) (discussing the medical arms race scenario).

22. The welfare effects of merger can be broken down into the impact of merger on producer and consumer surplus. "Producer surplus" can be equated with hospital profits. "Consumer surplus" represents the difference between how much an individual would be willing to pay for a product or service and how much the individual actually pays. See $\mathrm{HAL}_{\mathrm{AL}} \mathrm{R}$. Varian, Intermediate Microeconomics: A Modern ApProach 243-45 (1987) (defining consumer surplus). Loosely speaking, consumer surplus can be graphically represented by the area under a market demand curve and the line representing the market price. "Total welfare" is simply the sum of producer and consumer surplus. For further discussions of producer and consumer surplus, see infra Part III.A. For further technical discussions of consumer surplus, see generally Frank Camm; Consumer Surplus, Demand Functions, and Policy Analysis (1983).

23. A total welfare standard of merger review would permit any merger that increased total welfare, independent of the effect of merger on consumer surplus. A consumer surplus standard of merger review would prohibit a merger unless the parties demonstrated an increase in consumer surplus. For further discussion of the total welfare and consumer surplus standard, see infra Part III.D.

24. See sources cited supra note 2.

25. See studies cited infra note 98 . 
the preferences of consumers as aggregated by employers and other large third-party payors), justifying the traditional antitrust belief in the allocative efficiency of free markets. ${ }^{26}$ The Emerging Regime raises important questions about the appropriate antitrust policy for markets undergoing transition. Antitrust decisions affecting the structure of hospital markets today will influence whether and to what extent the promise of the Emerging Regime can be realized tomorrow. Permitting increases in hospital concentration, in a misguided effort to temper by-gone incentives for non-price rivalry, could pose a serious risk to the competitive structure of medical markets. ${ }^{27}$

\section{The Role of Presumptions in Merger Analysis}

\section{A. The Rebuttability of the Philadelphia Market-Share Rule}

Antitrust laws apply broadly to all sectors of the economy. Section 7 of the Clayton Act prohibits mergers and acquisitions where the effect "may be substantially to lessen competition, or to tend to create a monopoly." ${ }^{28}$ Throughout the 1960s the Supreme Court engaged in a series of hit or miss attempts to translate this legislative mandate into a set of judicially administrable rules and presumptions. The objective was to design a workable process for determining which mergers would "substantially lessen competi-

26. See Hammer, Price and Quality Competition, supra note 19 , at 133-34.

[T]o the extent that market outcomes in managed care markets reflect the actual choices of consumers between different price/quality combinations, the presumption that the level of quality provided by market forces is efficient (the basic assumption made by antitrust law) has a prima facie validity that it lacked in traditional health care markets.

Id.

27. This risk is compounded by the fact that producers have strong private incentives to impose capacity constraints when faced with the prospect of active price competition. See Hammer, Arrow, Coase and the Changing Structure of the Firm, supra note 16, at 37-40 (examining the pro-competitive virtues of "excess" capacity and the countervailing incentives that market participants have to establish capacity constraints). At the same time, there is a potential tradeoff between efficiency considerations and the structural intensity of price competition. Preserving capacity on the market is not costless, but from a policy perspective it may be worthwhile to purchase greater levels of competition through the preservation of excess capacity, even at the price of some degree of inefficiency. See id. at 40-41 (arguing that the pro-competitive virtues of excess capacity should be balanced against the inefficiencies associated with underutilized physical capacity).

28. 15 U.S.C. $\$ 18$ (1994). 
tion" and which would not. The result, as announced in Philadelphia National Bank, was a presumption inferring the existence of anticompetitive effects from a finding of economic concentration: ${ }^{29}$

[A] merger which produces a firm controlling an undue percentage share of the relevant market, and results in a significant increase in the concentration of firms in that market, is so inherently likely to lessen competition substantially that it must be enjoined in the absence of evidence clearly showing that the merger is not likely to have such anticompetitive effects. ${ }^{30}$

This approach left a number of questions unanswered. What threshold of economic concentration triggers the presumption of anticompetitive effects? Can the presumption be rebutted? If so, are the factual issues concerning the existence of market power and the theoretical inference of anticompetitive effects equally assailable? What type of evidence is sufficient to demonstrate that the effect of a merger will not be to "substantially lessen competition"?

Some of these questions were answered in United States $v$. General Dynamics. ${ }^{31}$ The central issue was whether the statistical evidence introduced by the government was sufficient to demonstrate the

29. See United States v. Philadelphia Nat'l Bank, 374 U.S. 321, 363 (1963). Philadelphia National Bank marked a departure from the multi-factored analysis the Court outlined earlier in Brown Shoe:

\begin{abstract}
Subsequent to the adoption of the 1950 amendments, both the Federal Trade Commission and the courts have, in light of Congress' expressed intent, recognized the relevance and importance of economic data that places any given merger under consideration within an industry framework almost inevitably unique in every case. Statistics reflecting the shares of the market controlled by the industry leaders and the parties to the merger are, of course, the primary index of market power; but only a further examination of the particular market-its structure, history and probable future-can provide the appropriate setting for judging the probable anticompetitive effect of the merger.
\end{abstract}

Brown Shoe Co. v. United States, 370 U.S. 294, 322 n.38 (1962). As part of this broadreaching inquiry, Brown Shoe identified a number of different factors that should be considered, including the degree of existing concentration in the market, trends toward increasing concentration, foreclosure of buyers within the market, and the ease or difficulty of new entry into the market. See id. at 322. In Philadelphia National Bank, the Court consciously adopted a more rule-based approach to section 7 , establishing a presumption of illegality based on market-share. The Court reasoned that "unless businessmen can assess the legal consequences of a merger with some confidence, sound business planning is retarded." Philadelphia Nat'l Bank, 374 U.S. at 362. The Court cautioned that it must "be alert to the danger of subverting congressional intent by permitting a too-broad economic investigation." Id.

30. Philadelphia Nat'l Bank, 374 U.S. at 363.

31. United States v. General Dynamics Corp., 415 U.S. 486 (1974). 
existence of market power. Market power is ordinarily inferred from market-share. In General Dynamics, however, the Court held that past market performance was not necessarily an indication of future market power. "Evidence of past production does not, as a matter of logic, necessarily give a proper picture of a company's future ability to compete." ${ }^{32}$ The Court reasoned that the best indication of future market power in the coal industry was uncommitted reserves. Finding that the merged party would have low uncommitted reserves, the Court held that the merger would not create market power, and thus there would be no anticompetitive effects. General Dynamics might be read to support the proposition that courts are willing to go behind the Philadelphia presumption. ${ }^{38}$ In reality, the inroads of General Dynamics are much narrower. General Dynamics only signified a willingness to treat the existence of market power as a factual issue properly open for dispute. What is important is that the Court did not question the theoretical inferences that would have been appropriate if a proper demonstration of market power had been made. ${ }^{34}$

32. Id. at 501 .

33. For an extensive discussion of General Dynamics and an examination of how lower courts have reacted to the decision, see Kaiser Aluminum $\mathcal{E}$ Chemical Comp. v. FTC, 652 F.2d 1324, 1335-40 (7th Gir. 1981). The Seventh Circuit rejected the FTC's narrow interpretation of General Dynamics and concluded that the decision signified a new willingness to permit economic evidence to rebut Philadelphia's market-share-based presumption:

The error in the Commission's approach to General Dynamics lies in the Commission's attempt to derive principles from the government's erroneous statistical measurement of market concentration in the coal industry, rather than rejecting that discredited analysis and accepting the rule that persuasive economic evidence can rebut a prima facie case bottomed on statistics of market share and concentration.

Id. at 1340 . Other courts have viewed General Dynamics as an attempt to refine, but not to substantially alter the rule-based approach outlined in Philadelphia:

Rather, we view General Dynamics as standing for the unremarkable proposition that a defendant may rebut the government's prima facie case by showing that the government's market share statistics overstate the acquired firm's ability to compete in the future and that, discounting the acquired firm's market-share to take this into account, the merger would not substantially lessen competition.

FTC v. University Health, Inc., 938 F.2d 1206, 1221 (11th Cir. 1991).

34. A number of questions remained unresolved in the wake of General Dynamics. To what extent did General Dynamics bring back the multifactored inquiry of Brown Shoe? To what extent should the General Dynamics factors capable of rebutting the Philadelphia presumption retain the characteristics of categorical, rule-based decision making? To what extent does General Dynamics permit or require courts to entertain direct evidence of the anticipated effects of market power in a particular industry? An extreme interpretation of General Dynamics would reduce the Philadelphia presumption to a mere burden-shifting rule. Evidence of high levels of economic concentration would shift the burden from the plaintiff to the defendants to demonstrate the absence of anticompetitive effects. In rebutting the 
While the Supreme Court has taken a noticeable hiatus from section 7 jurisprudence, the lower courts and the enforcement agencies have continued to refine the process of merger analysis. ${ }^{35}$ Courts increasingly speak in terms of market-share data creating a presumption of illegality, or as establishing a prima facie section 7 violation. ${ }^{36}$ Judges then stress the rebuttable nature of this

presumption, defendants would be entitled to engage in a broad, multi-factored inquiry, including the introduction of direct evidence as to the effect of market power. A more conservative approach would retain the categorical, rule-based structure of Philadelphia within the defendants' rebuttal case. High levels of market-share would support a presumption of anticompetitive effects that would shift the burden to defendants, but defendants would only be able to invoke structural economic considerations, such as the likelihood of entry, in rebutting the presumption. The conservative approach would limit the type of factors that could be considered under General Dynamics, and would potentially bar the introduction of direct evidence of the effects of market power in a given industry.

35. Government merger analysis under the Philadelphia formula is fairly straight forward: the enforcement agencies define the relevant market, calculate market-share, and prosecute those cases where they can establish a high level of post-merger economic concentration and a substantial increase in concentration levels attributable to the merger. See Horizontal Merger Guidelines $\$ 1$ (U.S. Dep't of Justice \& U.S. Federal Trade Commission, Apr. 2, 1992), reprinted in 4 Trade. Reg. Rep. (CCH) I 13,104 (1998) [hereinafter 1992 Guidelines]. Proof of a sufficiently high level of economic concentration establishes a presumption that the merged party will have market power, which in turn supports a presumption of anticompetitive effects. Defendants typically respond by attacking the government's definition of the market and by trying to "rebut" the presumption that economic concentration is persuasive evidence of market power by demonstrating that either no market power exists, or that market power cannot be successfully exercised.

In evaluating the merger between the two largest hospitals in Grand Rapids, Michigan, the Butterworth district court choreographed the process as follows:

The FTC may make a prima facie case by showing statistically that the proposed merger would produce an entity controlling an undue percentage share of the relevant market, and would result in a significant increase in concentration of power in that market. Establishment of this prima facie case creates a presumption of illegality which defendant hospitals may rebut through evidence undermining the predictive value of the FTC's statistics. If defendant hospitals successfully rebut the presumption, the burden of producing additional evidence of anticompetitive effect shifts to the FTC, which retains the ultimate burden of persuasion at all times.

FTC v. Butterworth Health Corp., 946 F. Supp. 1285, 1289 (W.D. Mich. 1996), affd without op., 121 F.3d 708, reported in full, 1997-2 Trade Cas. (CCH) I 71,863 (6th Cir. 1997) (citations omitted).

36. See Community Publishers, Inc. v. D.R. Partners, 139 F.3d 1180, 1184 (8th Cir. 1998) ("These high combined market shares of Stephens newspapers clearly raised a presumption that the acquisition violated Section 7."); University Health, 938 F.2d at 1218 (finding high levels of economic concentration trigger a presumption of illegality, creating a prima facie case under section 7); FTC v. Cardinal Health, Inc., 12 F. Supp. 2d 34, 52 (D.D.C. 1998) (stating that market-share data establishes a prima facie case); FTC v. Tenet Healthcare Corp., 17 F. Supp. 2d 937, 946 (E.D. Mo. 1998) ("The merger of Lucy Lee and DRMC is presumptively illegal under this test because the merged entity would acquire $84 \%$ of the relevant market."), rev'd, 186 F.3d 1045 (8th Cir. 1999) (rejecting the FTC's definition of the relevant market); United States v. Long Island Jewish Med. Ctr., 983 F. Supp. 121, 136 (E.D.N.Y. 1997) ("Generally, a plaintiff in a Section 7 Clayton Act antitrust matter may 


\section{presumption, frequently characterizing this rebuttability in broad and far-reaching terms. ${ }^{37}$ To phrase the central issue in}

establish a prima facie case by demonstrating that the merged entity will have a large percentage of the 'relevant market,' so that it may raise prices above competitive levels."); FTC v. Staples, Inc., 970 F. Supp. 1066, 1083 (D.D.C. 1997) ("By showing that the proposed transaction between Staples and Office Depot will lead to undue concentration in the market for consumable office supplies sold by office superstores in the geographic markets agreed upon by the parties, the Commission establishes a presumption that the transaction will substantially lessen competition."); Butterworth, 946 F. Supp. at 1294 ("A transaction resulting in a high concentration of market power and creating, enhancing, or facilitating a potential that such market power could be exercised in anticompetitive ways is presumptively unlawful.”); United States v. Mercy Health Servs., 902 F. Supp. 968, 975 (N.D. Iowa 1995) ("The government may make a prima facie showing that the merger will result in anticompetitive effects by showing that the merged entity will have an undue share of the relevant market."), vacated and remanded, 107 F.3d 632 (8th Cir. 1997) (remanding to district court with instructions to dismiss as moot because the parties abandoned their intentions to merge); United States v. United Tote, Inc., 768 F. Supp. 1064, 1068 (D. Del. 1991) ("If it demonstrates that the merger further consolidates an already highly concentrated market for a given product, the Government establishes a rebuttable presumption that the merger is illegal under Section 7."); United States v. Country Lake Foods, Inc., 754 F. Supp. 669, 678 (D. Minn. 1990) ("The Court finds that if the government established that the MSP/MSA is the relevant geographic market, then, under Philadelphia National Bank it would be entitled to a presumption of a prima facie violation of Section 7."); FTC v. Promodes S.A., 1989-2 Trade Cas. (CCH) I 68,688, at 61,626 (N.D. Ga. 1989) ("This high market concentration raises a presumption of illegality under Section 7 of the Clayton Act."); California v. American Stores Co., 697 F. Supp. 1125, 1128 (C.D. Cal. 1988) ("Statistical evidence of market share and concentration resulting from a merger can establish a prima facie case or the presumption that the proposed merger would substantially lessen competition in violation of the Clayton Act."), affd in part and rev'd in part, 872 F.2d 837, 842 (9th Cir. 1989) ("Statistics that indicate excessive post-merger market share and market concentration create a presumption that the merger violates the Clayton Act."), rev'd and remanded on other grounds, 495 U.S. 271 (1990).

37. See University Health, 938 F.2d at 1218 (holding that the presumption is rebuttable); R.C. Bigelow, Inc. v. Unilever N.V., 867 F.2d 102, 110 (2nd Cir. 1989) (stating that "market share data that does not accurately reflect probable market power may not be relied upon to invalidate a merger"); Kaiser Aluminum, 652 F.2d at 1341 ("Nonstatistical evidence which casts doubt on the persuasive quality of the statistics to predict future anticompetitive consequences may be offered to rebut the prima facie case made out by the statistics."); Cardinal Health, 12 F. Supp. 2d at 54 (finding rebuttal of the prima facie case); Staples, 970 F. Supp. at 1083 ("Once such a presumption has been established, the burden of producing evidence to rebut the presumption shifts to the defendants. To meet this burden, the defendants must show that the market-share statistics give an inaccurate prediction of the proposed acquisition's probable effect on competition.") (citations omitted); Butterworth, 946 F. Supp. at 1294 ("In order to prevent injunctive relief, defendants must rebut this prima facie case by showing under the facts of this case, notwithstanding the statistical evidence, that the proposed merger is not likely to result in anticompetitive effects."); Mercy Health, 902 F. Supp. at 976 ("If the government is able to make a prima facie case, the defendants can overcome the presumption of illegality by showing that the market-share analysis gives an inaccurate reflection of the acquisition's probable effect on competition within the relevant market."); United States v. Gillette Co., 828 F. Supp. 78, 84 (D.D.C. 1993) (“Defendants, however, may-and in this case, do-rebut [the Philadelphia] presumption.”); United Tote, 768 F. Supp. at 1070 ("Accordingly, United Tote may successfully rebut the Government's statistical case by affirmatively showing that the merger between itself and Autotote is unlikely to substantially lessen competition or by discrediting the data underlying the Government's prima 
section 7 analysis in terms of a rebuttable presumption of illegality invites merging defendants to aggressively explore means of overcoming this presumption and countering the government's prima facie case. The list of factors potentially capable of rebutting the market-share-based presumption is lengthy and growing. ${ }^{98}$ The factors include: (1) ease of entry,

facie case."); Country Lake Foods, 754 F. Supp. at 674 (stating that "this high concentration warrants a presumption that a prima facie violation of Section 7 has been established, unless defendants present clear evidence that the proposed acquisition is not likely to have such anticompetitive effects"); Promodes, 1989-2 Trade Cas. at 61,626 ("Nevertheless, a high market share does not establish a per se violation of Section 7. Market share data that does not accurately reflect probable market power may not be relied upon to invalidate a merger.") (citations omitted); American Stores, 697 F. Supp. at 1128 ("The presumption of a Clayton Act violation based on the post-merger market statistics is not conclusive and can be overcome, but only by a showing that the statistics do not accurately reflect the probable effect of the proposed merger on competition."), aff d, 872 F.2d at 843 (holding that the presumption can be rebutted by evidence demonstrating that market-share data inaccurately portrays the merger's probable effect on competition).

38. Many of the considerations relevant to the inquiry are similar to those identified in Brown Shoe. See Kaiser Aluminum, 652 F.2d at 1341.

Among the factors to be considered might be ease of entry into the market, the trend of the market either toward or away from concentration, and the continuation of active price competition. In some cases unique economic circumstances might make other factors significant, e.g., the genuine independence of the acquired company ... or the merger of two small firms to survive competitively in a market, or the demand of a market for large producers.

Id; see also Remington Prod., Inc. v. North Am. Philips Corp., 717 F. Supp. 36, 44 (D. Conn. 1989) ("Although market shares are the 'primary indicia of market power' courts may view other economic and historical factors. These factors may include: (1) concentration in the industry; (2) ease of entry into the market; (3) strength of remaining firms; (4) supply and demand in the market; and (5) post-acquisition events.") (citations omitted).

39. See Cardinal Health, 12 F. Supp. 2d at 55 ("A court's finding that there exists ease of entry into the relevant product market can be sufficient to offset the government's prima facie case of anti-competitiveness."); Staples, 970 F. Supp. at 1086.

If the defendants' evidence regarding entry showed that the Commission's market-share statistics give an incorrect prediction of the proposed acquisition's probable effect on competition because entry into the market would likely avert any anti-competitive effect by acting as a constraint on Staples-Office Depot's prices, the Court would deny the FTC's motion. The Court, however, cannot make such a finding in this case.

Id.; see also Community Publishers, 139 F.3d at 1184 ("Further, the court found that NAT and Donrey had failed to rebut the presumption of illegality. In particular, the court found that barriers to entry are formidable in the local daily newspaper business ....); Long Island Jewish Med. Ctr., 983 F. Supp. at 149 ("A merger is not likely to cause an anti-competitive effect if other participants can enter the relevant markets and reduce the likelihood of a price increase above competitive levels."); FTC v. Freeman Hosp., 911 F. Supp. 1213, 1223 (W.D. Mo.) ("In assessing competitive effects, the Court must also evaluate the possibility and likelihood of new competitors entering the relevant geographic market."), affd, 69 F.3d 260 (8th Cir. 1995); United Tote, 768 F. Supp. at 1071 ("United Tote's second argument is that it is so easy to enter the totalistor market that high market share does not accurately 


\section{efficiency, ${ }^{40}$ (3) "flailing company" or weak competitor status, ${ }^{41}$ (4) the presence of large sophisticated buyers, ${ }^{42}$ (5) nonprofit}

reflect an ability to exercise market power."); Country Lake Foods, 754 F. Supp. at 679 ("First, defendants assert that low entry barriers exist, making it unlikely that a price increase could be sustained because new competitors would enter the market and offer lower prices."); Promodes, 1989-2 Trade Cas. at 61,626 (implying that evidence of likely entry is sufficient to rebut presumption of anticompetitive effects); American Stores, 697 F. Supp. at 1131-32 (considering and rejecting defendant's entry argument); McCaw Personal Communications, Inc. v. Pacific Telesis Group, 645 F. Supp. 1166, 1174 (N.D. Cal. 1986) ("The existence of low barriers to entry may rebut a prima facie showing of illegality, even where the combined market shares of the merged firms is quite high.").

40. See University Health, 938 F.2d at 1222 ("We conclude that in certain circumstances, a defendant may rebut the government's prima facie case with evidence showing that the intended merger would create significant efficiencies in the relevant market."); Long Island Jewish Med. Ctr., 983 F. Supp. at 146-47 (entertaining hospital's argument that efficiencies could rebut the presumption of anticompetitive effects); Butterworth, 946 F. Supp. at 1300-01 (stating that efficiency gains can rebut the presumption of anticompetitive effects); Country Lake Foods, 754 F. Supp. at 680 ("The Court finds these efficiencies relevant, not so much as an independent factor justifying the proposed acquisition, but as further evidence that the proposed acquisition will enhance competition.") (citations omitted). But see Staples, 970 F. Supp. at 1089 ("Assuming that it is a viable defense, however, the Court cannot find in this case that the defendants' efficiencies evidence rebuts the presumption that the merger may substantially lessen competition or shows that the Commission's evidence gives an inaccurate prediction of the proposed acquisition's probable effect.").

41. See University Health, 938 F.2d at 1221 ('The acquired firm's weakness, then, is one of many possible factors that a defendant may introduce to rebut the government's prima facie case."); Freeman Hospital, 911 F. Supp. at 1225 (noting the hospital's declining admissions and revenues and the hospital's "limited future of only two to three years" in assessing the competitive effects of the merger). But see Kaiser Aluminum, 652 F.2d at 1341 ("[T] financial weakness of the acquired firm, while it may be a relevant factor in some cases, certainly cannot be the primary justification of a merger in resistance to a $\$ 7$ proceeding."); Tenet Healthcare, 17 F. Supp. 2d at 947 (rejecting the hospital's "flailing firm" defense as a factual matter, reasoning that "[f]inancial weakness may constitute a defense to an antitrust suit only where 'the defendant makes a substantial showing that the acquired firm's weakness, which cannot be resolved by any competitive means, would cause that firm's market share to reduce to a level that would undermine the government's prima facie case." ") (quoting University Health, 938 F.2d at 1221). The "weak" or "flailing" firm argument is similar to the failing firm defense, which applies when defendants demonstrate a grave probability of business failure and the absence of any other prospective purchaser. See Citizen Pub. Co. v. United States, 394 U.S. 131, 136-38 (1969). The failing firm defense is subject to different doctrinal interpretations. It may indicate a social policy benefiting weak or failing businesses. Alternatively, it can be rationalized within the Philadelphia framework as evidence that the merger will not increase market power due to the extremely weakened status of one of the merging parties.

42. There in no consistent theory as to why the presence of sophisticated buyers should be capable of rebutting the Philadelphia presumption. Some courts use the reaction of buyers as a proxy to assess the likely competitive effects of merger on the assumption that the absence of buyer opposition is evidence of the absence of likely anticompetitive effects. See Freeman Hosp., 911 F. Supp. at 1223 ("The market for hospital services in the Joplin area is dominated by large, sophisticated payors. Notably, no third-party payor or customers have expressly objected to this consolidation."); Long Island Jewish Med. Ctr., 983 F. Supp. at 144.

Dr. Stocker, the spokesman for Empire, a prominent, multifaceted MCO, and with almost 5 million insureds, alleged to be the largest payer in the market (Tr. at 21516), was of the opinion that the merger was 'a good idea ... [and] would help drive 


\section{status, ${ }^{43}(6)$ changing market conditions, ${ }^{44}$ (7) direct evidence that mergers will not increase prices, ${ }^{45}$ and ( 8 ) promises by the merging}

down costs.' Rather then being anti-competitive, he believed it would decrease prices

$\cdots$

Id.

Other courts, whether they are persuaded on the particular facts of the case or not, appear to believe that sophisticated buyers can use their "power" to offset the merged sellers market power. See Country Lake Foods, 754 F. Supp. at 679 ("The most persuasive argument proffered by defendants to rebut the presumption of violation of Section 7 is the power of the buyers in the MSP/MSA. Defendants contend that this power precludes the exercise of market power by the dairies.").

Some courts have treated buyer sophistication as a factor in examining the ability of sellers to collude in the post-merger market. See University Health, 938 F.2d at 1213, n.13 (noting that large sophisticated buyers may be relevant to the issue of seller collusion, but concluding that the actual buyer was the individual patient and not the larger insurance company).

Other courts have rejected the presence of sophisticated buyers as a consideration capable of rebutting market-share presumptions. The defendant in United Tote argued that the market was dominated by large sophisticated buyers and that these buyers did not object to the merger. The court rejected the argument, stating, "the Court finds that the presence of some large sophisticated consumers in the North American totalisator market would not be sufficient to offset the anti-competitive effects of the merger." United Tote, 768 F. Supp. at 1084-85; see also Cardinal Health, 12 F. Supp. 2d at 61 ("In the end, although this Court finds that buyer power does exist in whole market... and is worthy of consideration, it alone cannot rebut the Government's prima facie case."). For an academic treatment of the role of buyer sophistication in section 7 cases, see Hovenkamp, supra note 3, at 477-82; Michael S. Jacobs, The New Sophistication in Antitrust, 79 Minn. L. Rev. 1, 8-12 (1994).

43. See Long Island Jewish Med. Cir., 983 F. Supp. at 146 (“[T] he Court deduces that while the not-for-profit status of the merging hospitals does not provide an exemption from the antitrust laws, this factor may be considered if supported by other evidence that such status would inhibit anti-competitive effects."); Butterworth, 946 F. Supp. at 1296-97 ("The nonprofit status of the hospitals is not a dispositive consideration, but it is material.... These findings suggest that a substantial increase in market concentration among nonprofit hospitals is not likely to result in price increases."); Freeman Hosp., 911 F. Supp. at 1222-23 (characterizing a local nonprofit hospital as a "consumer cooperative" and noting that "it would not be in these individual Board member's best economic interest to permit prices to be raised beyond a normal competitive level"). But see University Health, 938 F.2d at 1224 ("Thus, the nonprofit status of the acquiring firm will not, by itself, help a defendant overcome the presumption of illegality that arises from the government's prima facie case.").

44. Changing market conditions was a factor advanced by the defendant in United Tote.

United Tote argues that the racing industry is experiencing dramatic changes, including consolidation or wagering networks into statewide or regional systems, interstate commingling of betting pools, blending of lottery and racing wagers, growth of off-track betting and the advent of sports wagering. United Tote asserts that, without merger, United will be unable to sustain the research, development, production and service efforts that an increasingly complex racing industry will demand.

United Tote, 768 F. Supp. at 1082 . The court considered but was not persuaded by the argument. See id. at 1082-84.

45. Direct evidence concerning the effects of market power has been considered under a number of different guises. The defendants in Butterworth introduced econometric evidence of the effect of market power on the pricing behavior of nonprofit hospitals. See Butterworth, 946 F. Supp. at 1295 ("Defendants begin their rebuttal by arguing that high 
parties not to behave anticompetitively, such as promises not to raise prices. ${ }^{46}$

Unfortunately, this list of factors does not establish a coherent framework in which to assess how or when the Philadelphia presumption should be rebutted. In my view, the rule in Philadelphia can best be understood in terms of a two-step formula. The first step equates market-share with market power. The second step equates market power with anticompetitive effects. The first step involves a factual inquiry into the existence of market power (using market-share as a proxy), while the second step reflects a purely theoretical inference of anticompetitive effects from a finding of market power.

Many of the post-General Dynamics developments simply flesh out the contestability of the first step of the Philadelphia formula. ${ }^{47}$ The

concentration in the hospital industry should not be presumed to result in anticompetitive effects. Specifically, defendants contend that empirical proof does not support the presumption that high concentration of market power among nonprofit hospitals results in price increases."). In other cases, the defendants attempt to use direct evidence to attack or undermine the government's theory or statistics. See Staples, 970 F. Supp. at 1083-86 (considering defendant's evidence directly challenging the likely connection between market-share and price in the market of office supplies); United Tote, 768 F. Supp. at 1070-71 (considering defendants' challenge to the government's methodology for defining markets and projecting price increases). In some cases, courts have used testimony from large buyers as direct evidence of the likely effects of merger. See Long Island Jewish Med. Ctr., 983 F. Supp. at 143-45; Freeman Hosp., 911 F. Supp. at 1223-24.

46. The defendants in Butterworth made such promises:

In the way of additional assurance that the merged entity would not exercise its market power to raise prices or otherwise injure the community, defendants offer the 'Community Commitment.' . . . The Community Commitment has five parts: (1) the commitment to freeze list prices or charges, (2) the commitment to freeze prices to managed care plans at pre-merger levels, (3) the commitment to limit margins, (4) the commitment to the underserved and medically needy, and (5) the commitment regarding governance of the merged entity.

Butterworth, 946 F. Supp. at 1298; see also Long Island Jewish Med. Ctr., 983 F. Supp. at 144 ("Further, NSM and LIJ have stipulated with the New York State Attorney General not to raise prices for at least two years after the merger is consummated."). But see University Health, 938 F.2d at 1224 ("University Hospital's business decisions are not mandated by law; rather, its governing body is free to decide where to set prices and output. While University Hospital's prior practices may suggest its future conduct, such evidence has limited probative value. The appellees' self-serving declarations simply do little to undermine the impressive evidence the FTC has introduced to make its case.")

47. The current enforcement agencies' merger guidelines are illustrative. The central focus of the 1992 Guidelines is on defining economic markets (product and geographic), and calculating levels of concentration. See 1992 Guidelines, supra note $35, \S \S 1.1,1.2,1.4$. Prosecutorial decisions are directly tied to the resulting concentration ratios. See id. $\$ 1.5$. The Guidelines analysis of market entry, see id. $\$ 3$, and the range of economic factors that might facilitate collusion, see id. $\S 2.1$, proceed to address whether market power, if it is proven to exist, can be exercised. With the notable exception of economic efficiencies, see id. $\S 4$, the inquiry does not focuses on the second step of the Philadelphia formula-whether 
market power inquiry has been bifurcated into an assessment of whether market power exists (the process of defining product and geographic markets and calculating levels of economic concentration) and whether market power can be exercised (arguments focusing on factors such as ease of market entry and the various considerations that may facilitate collusion). ${ }^{48}$ These refinements represent logical efforts to test the robustness and veracity of the defined market, and to further assess whether high levels of concentration in the defined market can fairly be equated with market power. Other aspects of the post-General Dynamics developments, however, do not fit neatly within this characterization.

\section{B. Efficiency and Balancing Under Section 7}

Efficiency arguments present a more direct challenge to the Philadelphia/General Dynamics framework. Efficiency arguments do not deny the existence of market power, nor do they suggest that market power cannot be exercised. Indeed, certain efficiencies are achieved only at scales that necessarily entail the creation of market power and the production of anticompetitive effects: the relatively higher prices, reduced output, and allocative inefficiency represented by the monopolist's dead weight loss triangle. ${ }^{49}$ Rather than denying the reality of anticompetitive effects, these arguments contend that efficiency gains should be balanced against anticompetitive harms, and that mergers should be permitted if the efficiency gains outweigh the anticompetitive losses. ${ }^{50}$ The prospect of balancing the pro- and anti-competitive effects of merger raises doctrinal questions that go beyond Philadelphia and General Dynamics

market power produces undesirable consequences, or whether alleged pro-competitive benefits of merger can be balanced against acknowledged anti-competitive effects. The central role of market-share rules and presumptions in the 1992 Guidelines is similar to earlier DOJ versions. See Thomas E. Kauper, The 1982 Horizontal Merger Guidelines: Of Collusion, Efficiency, and Failure, 71 CAL. L. REv. 497, 497 n.2, 505-10 (1983) (examining the role of presumptions and market-share rules under the 1968 and 1982 DOJ Horizontal Merger Guidelines).

48. These inquiries are obviously related and frequently overlap. The difference between a narrowly defined market with a finding of substantial likelihood of entry, and a more broadly defined market that includes the potential entrant is often a matter of characterization and timing.

49. See Oliver E. Williamson, Economies as an Antitrust Defense: The Welfare Tradeoffs, 58 AM. Econ. Rev. 18, 22 (1968) (discussing the anti-competitive effects of market power).

50. See id. at 21-23 (outlining the classic framework in which the anti-competitive effects of merger are balanced against increases in productive efficiency); see also HovenkAMP, supra note 3, at 452-55 (explaining Williamson's tradeoff model). 
and require further refinement of the discussion of the refutability of market-share rules. ${ }^{51}$

It is helpful to construct a decision tree that illustrates various possible approaches to section 7 of the Clayton Act.

\section{Figure One \\ Decision Tree for Section 7 Analysis}

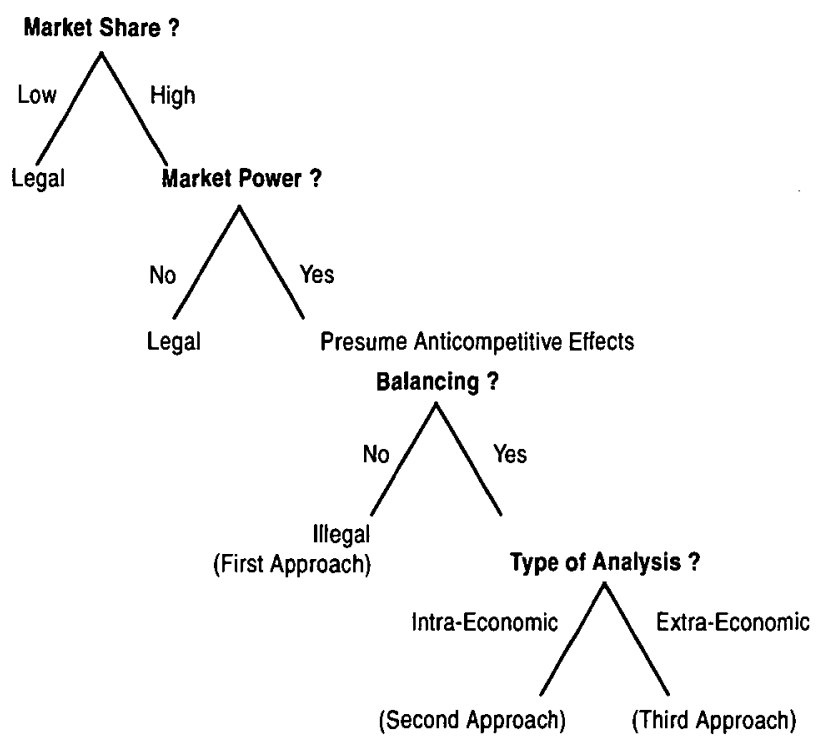

51. The fact that efficiency claims raise issues that go beyond the Philadelphia framework is not surprising. Philadelphia was decided in an era that implicitly rejected the viability of an efficiency defense in merger cases. See FTC v. Procter \& Gamble Co., 386 U.S. 568, 580 (1967) ("Possible economies cannot be used as a defense to illegality."); Brown Shoe Co. v. United States, 370 U.S. 294, 344 (1962) ("Congress appreciated that occasional higher costs and prices might result from the maintenance of fragmented industries and markets. It resolved these competing considerations in favor of deconcentration."). Since General Dynamics, the Court has recognized the importance of efficiency concerns and economic analysis in other antitrust contexts. See, e.g., Monsanto Co. v. Spray-Rite Serv. Corp., 465 U.S. 752, 762 (1984) ("In Sylvania we emphasized that the legality of arguably anticompetitive conduct should be judged primarily by its 'market impact.' "); Continental T.V., Inc. v. GTE Sylvania Inc., 433 U.S. 36, 49 (1977) ("Under [the rule of reason], the factfinder weighs all of the circumstances of a case in deciding whether a restrictive practice should be prohibited as imposing an unreasonable restraint on competition."). In the last 10 years, an increasing number of lower courts have acknowledged the viability of efficiency claims in merger cases. See cases cited supra note 40. Similarly, both federal enforcement agencies now acknowledge the validity of efficiency arguments. See 1992 Guidelines, supra note $35, \S 4$. These developments raise questions as to how efficiency concerns can best be layered over the framework developed in Philadelphia and General Dynamics. 
The nodes of the decision tree in Figure One correspond to (1) the presence or absence of high levels of economic concentration (market-share); (2) the presence or absence of market power; (3) whether courts will "balance" the possible benefits of merger against the anticompetitive effects of merger; and (4) if balancing is permitted, whether such balancing takes place within an intraeconomic paradigm or an extra-economic paradigm.

Within this framework, there are three different antitrust approaches to the question of balancing and the rebuttability of the Philadelphia presumption. The first approach rejects any concept of balancing and rests section 7 liability strictly upon a finding of anticompetitive effects. High levels of concentration in a properly defined market would support a presumption of anticompetitive effects, which could only be rebutted by evidence suggesting either that no market power really existed or that such power could not be exercised. The second and third approaches permit alleged benefits of merger to be "balanced" against anticompetitive effects, but differ on the type of benefits that could be considered. The second approach permits intra-economic balancing: balancing that takes place within the context of traditional welfare economics and considers only economic benefits, such as increased productive or allocative efficiency. The third approach permits extra-economic balancing. By extra-economic balancing, I mean that judges could consider a broad range of potential benefits of merger, including non-economic policies and objectives. In assessing the likelihood and magnitude of anticompetitive effects, however, both the second and third approach use methods identical to the firstmarket-share presumptions and inferences about anticompetitive effects based on findings of market power. ${ }^{52}$

How do the various factors courts deem capable of rebutting the Philadelphia presumption fit within these approaches? The first approach is concerned solely with structural economic characteristics suggesting either that high levels of market-share cannot be equated with market power, or that market power, if it does exist, cannot be exercised. Entry analysis plays a central role. The existence of failing, flailing, or weak competitors is relevant only to the extent it suggests that market-share data overstates the presence of market power. Large sophisticated buyers are relevant only to the extent they suggest it would be difficult to collude in a

52. Obviously, one could envision permutations within the first two nodes of the decision tree regarding the type and range of factors capable of rebutting the presumption that market-share can be associated with market power. For simplicity, and to permit the focus to remain on the role of balancing, these permutations are not explored here. 
post-merger environment, or that buyers were a potential source of entry through vertical integration. Factors such as nonprofit status, or promises by the parties not to raise prices, would not be relevant. Perhaps most significantly, this approach would reject any efficiency defense. The court's inquiry would end with a finding of anticompetitive effects based upon a finding of market power. Alleged efficiency gains could not save an otherwise anticompetitive merger. ${ }^{53}$ Strong presumptions and a refusal to balance alleged benefits of merger channel these issues out of the judicial system and establish a well-defined division of labor between judges and legislators.

The second approach embraces the structural economic considerations of the first in assessing the likelihood and magnitude of the anticompetitive effects, but permits courts to consider potential economic benefits of merger. For example, courts may balance efficiencies against acknowledged anticompetitive effects. Although the existing case law focuses primarily on productive efficiency, intra-economic balancing would permit consideration of other economic benefits, such as the increase in allocative efficiency that might result from reductions in rent-dissipating forms of non-price competition. ${ }^{54}$

Advocates of intra-economic balancing are divided in terms of whether such balancing should be conducted under a total welfare or a consumer surplus standard. This distinction is important in

53. This approach is consistent with the DOJ's 1968 merger guidelines. See U.S. Department of Justice 1968 Merger Guidelines, reprinted in 4 Trade Reg. Rep. (CCH) 1 13,101, $\$ 10$ (1968) (stating that " $[\mathrm{u}]$ nless there are exceptional circumstances, the Department will not accept as a justification for an acquisition normally subject to challenge under its horizontal merger standards, the claim that the merger will produce economies (i.e., improvements in efficiency) ${ }^{n}$ ). The decision not to recognize an efficiency defense, does not mean that efficiency concerns played no role in the 1968 Guidelines. The Guidelines attempted to accommodate efficiency concerns in their determination of the concentration thresholds at which market power would be challenged, on the expectation that most significant scale economies could be exhausted below such thresholds. See id. \$§ 5-6.

54. Advocates of an efficiency defense often expressly limit the scope of such a defense to productive efficiency concerns. See, e.g., 4 Phillip Areeda \& Donald Turner, AntiTRUST LAW I 949-52, at 175-81 (1980) (focusing on efficiencies such as plant size and specialization economies); Robert Pitofsky, Proposals for Revised United States Merger Enforcement in a Global Economy, 81 GEo. L.J. 195, 216 (1992) ("Efficiencies claims should be limited to situations in which there is reliable proof that the merger would reduce by a significant amount the unit costs of production."). These limitations are due to evidentiary concerns and worries about the institutional capacities of the courts. The bias in favor of productive efficiency claims is hard to justify on theoretical grounds. Conceptually, courts and policymakers should be concerned about the effects of merger on allocative efficiency as well as on productive efficiency. For a discussion of the various efficiency defenses that have been advocated and how they differ mechanically from each other, see Andrew G. Berg, Cost Efficiencies in the Section 7 Calculus: A Review of the Doctrine, 37 CASE W. RES. L. REv. 218, 239-57 (1986). 
assessing the relevance of some of the post-General Dynamics factors. While nonprofit status would not rebut the presumption that market power produces anticompetitive effects, nonprofit status might be relevant in assessing the distributional effects of merger. Distributional effects are relevant under the consumer surplus standard because the economic benefits of merger must be "passed on" in some form to consumers. ${ }^{55}$ Intra-economic balancing assigns judges more discretion in merger review than the first approach, but seeks to constrain that discretion by limiting considerations of the effects of merger to economic factors. Extra-economic goals and objectives are still channeled out of the courts and into the legislative forum.

The third approach permits the anticompetitive effects of merger to be balanced against a wide range of potential social benefits. A merger may be permitted either because it furthered specific extraeconomic goals or because the court believed that non-market institutions constituted a superior means of allocating social resources. For example, a court may believe that a nonprofit, community-based hospital board, unconstrained by the demands of competition, would make superior decisions concerning the allocation of health care resources than would a hospital in a market-based system predicated on direct rivalry. Within the extra-economic context of the third approach, nonprofit status and the expressed intentions and promises of the merging parties might be important in assessing the legality of mergers.

The extra-economic balancing of the third approach stands on tenuous doctrinal grounds. Neither courts nor merging parties expressly frame their arguments in terms of embracing noneconomic factors. The extra-economic balancing typically occurs implicitly, either by improperly expanding the factors that rebut the Philadelphia market-share presumption, or by improperly characterizing as "efficiencies" a variety of non-economic benefits of merger. It is useful to choreograph section 7 analysis as done in figure one and to focus on balancing within an extra-economic paradigm, however, precisely because it makes the doctrinal problems with these contentions transparent. Section 7 analysis takes place in the shadow of antitrust law's strong belief in the efficiency of competitive markets. Consequently, extra-economic arguments in favor of market power have typically received a chilly reception from the Court.

55. See cases cited infra note 93 (requiring the efficiency benefits of merger to be "passed on" to consumers). 
In National Society of Professional Engineers $v$. United States, ${ }^{56}$ the Court summarily rejected the claim that markets could not adequately provide for public health, welfare and safety as "nothing less than a frontal assault on the basic policy of the Sherman Act." The Court's faith in markets applies to non-price as well as price competition, and to markets for professional as well as nonprofessional services. "The assumption that competition is the best method of allocating resources in a free market recognizes that all elements of a bargain-quality, service, safety, and durability-and not just the immediate cost, are favorably affected by the free opportunity to select among alternative offers." ${ }^{~} 58$ In Indiana Federation of Dentists, ${ }^{59}$ the Court invalidated a practice among dentists of collectively refusing to submit $x$-rays to insurance companies for evaluation by third-party payors in utilization review programs. The Court held that the practice interfered with the ability of unconstrained market forces to provide the appropriate allocation of medical services:

A refusal to compete with respect to the package of services offered to customers, no less than a refusal to compete with respect to the price term of an agreement, impairs the ability of the market to advance social welfare by ensuring the provision of desired goods and services to consumers at a price approximating the marginal cost of providing them. ${ }^{60}$

The Court rejected claims that consumers would be unable to make educated decisions, as well as the claim that the provision of $\mathrm{x}$-rays would threaten quality of care. ${ }^{61}$

56. 435 U.S. 679 (1978). In Professional Engineers, the Court struck down an ethical cannon that prohibited competitive bidding. The Society argued that the prohibition was necessary because competitive bidding allegedly resulted in inferior work and a threat to public health and safety. See id. at 684-85. The Court was unwilling to question the ability of the market to function effectively in ensuring adequate levels of safety. Instead, the Court viewed the market as the most reliable mechanism to make these cost/quality tradeoffs. See id. at 694-95.

57. Id. at 695 .

58. Id.

59. FTC v. Indiana Federation of Dentists, 476 U.S. 447, 466 (1986).

60. Id. at 459 .

61. See id. at 462-63. The general reluctance to question the effects of market power has made the Court unsympathetic to claims that the medical industry is somehow different from other industries, or that medical markets warrant special antitrust consideration. The Court responded hostilely to the argument that the per se rule against price fixing should not apply to the medical industry. See Arizona v. Maricopa County Med. Soc'y, 457 U.S. 332, $349-51^{\prime}$ (1982) (rejecting arguments by the court of appeals that the health care industry was too far removed from the competitive model to make traditional antitrust analysis applicable). The contention that courts will not recognize a separate set of antitrust rules in health 
This faith in the efficiency of markets presents a serious challenge to advocates of extra-economic balancing, including proponents of many hospital mergers. Hospitals claim that mergers, even those that create market power, are potentially desirable because they can reduce wasteful non-price competition, produce a superior distribution of resources, or reduce prices. ${ }^{62}$ These claims directly challenge the efficiency of competition in health care markets. While some of the hospitals' non-price contentions can ultimately be brought under the umbrella of the intraeconomic analysis characteristic of the second approach, many other aspects of the hospitals' arguments cannot.

\section{The Presumption That Non-Price Competition Is Desirable}

\section{A. Non-Price Competition: Economic and Distributional Concerns}

This Article began with the surprising finding that hospital competition in the Old Regime can lead to higher medical expenses. $^{63}$ If this is true, then increases in economic concentration

care cases was reinforced in Jefferson Parish Hospital District No. 2 v. Hyde, 466 U.S. 2 (1984). The Court refused to sanction restraints that were allegedly justified for health care reasons. "Thus, we reject the view of the District Court that the legality of an arrangement of this kind turns on whether it was adopted for the purpose of improving patient care." Id. at 25 n.41. The fact that the alleged illegal tying arrangement concerned the health care industry did not change the Court's substantive antitrust analysis. "In the past, we have refused to tolerate manifestly anticompetitive conduct simply because the health care industry is involved." Id. at 25-26 n.42 (citing cases).

62. The hospitals' non-price contentions are addressed infra Part III. The hospitals' price contentions are addressed infra Part IV.

63. See sources cited supra note 1. The problems surrounding hospital mergers have generated substantial scholarly attention. See generally Gloria J. Bazzoli et al., Federal Antitrust Merger Enforcement Standards: A Good Fit for the Hospital Industry?, 20 J. HealTh Pol. PoL'y \& L. 137 (1995); Michael D. Belsley, The Vatican Merger Defense-Should Two Catholic Hospitals Seeking to Merge Be Considered a Single Entity for Purposes of Antitrust Merger Analysis?, $90 \mathrm{Nw}$. U. L. REv. 720 (1996); Thomas L. Greaney, Regulating for Efficiency in Health Care Through the Antitrust Laws, 1995 UTAH L. Rev. 465; Dayna B. Matthew, Doing What Comes Naturally: Antitrust Law and Hospital Mergers, 31 Hous. L. REv. 813 (1994); Gregory Vistnes, Hospital Mergers and Antitrust Enforcement, 20 J. Health Pol. PoL'y \& L. 175 (1995); Michael G. Vita et al., Economic Analysis in Health Care Antitrust, 7 J. Contemp. Health L. \& Pol'y 73 (1991); Dennis A. Yao, The Analysis of Hospital Mergers and Joint Ventures: What May Change?, 1995 Utah L. Rev. 381; Stephen Paul Paschall, Comment, Antitrust and Hospital Mergers: A Law and Economics Rationale for Exemption, 30 DuQ. L. REv. 61 (1991). Almost the entire Spring 1999 issue of ANTITRust is devoted to the problems raised by hospital mergers. See Jeffrey W. Brennan and Paul C. Cuomo, The "Nonprofit Defense" in Hospital Merger Antitrust Litigation, AntrTrust, Spring 1999 at 13; Monica Noether, Overview: Economic Issues in 
should be associated with lower health care costs. This possibility leads to a superficially appealing argument in favor of hospital mergers. Unfortunately, the problem is slightly more complicated than the simple relationship between market power and medical costs might suggest. The correlation between economic concentration and higher medical costs is best explained by the effects of market structure on non-price competition. Mergers decrease costs by decreasing the provision of non-price services; whether such reductions are desirable as a matter of health care policy depends upon the social value of the non-price services that are eliminated.

One can construct a model of hospital competition establishing a direct relationship between the intensity of non-price competition and the number of hospitals in the market. ${ }^{64}$ In this model, increasing the number of hospitals increases the level of non-price attributes hospitals provide. Correspondingly, decreasing the number of hospitals decreases the amount of non-price competition. Non-price competition, in turn, is directly related to hospital costs. The higher the level of non-price competition, the higher the level of hospital-specific and market-wide medical expenses. Consequently, one would expect mergers in the Old Regime (and economic concentration in general) to be associated with lower costs, not necessarily as a result of increased productive efficiency, but as a result of decreased non-price competition. ${ }^{65}$

Given that mergers decrease costs by decreasing the level of nonprice services, it is necessary to explore the welfare and distributional implications of merger. The impact of hospital mergers can be

Hospital Merger Policy, supra, at 6; Richard D. Raskin and Bruce M. Zessar, Telling the Efficiency Story: Practical Lessons from the Hospital Merger Field, ANTITRuST, supra, at 21; Gregory S. Vistnes, Defining Geographic Markets for Hospital Mergers, ANTITRust, supra, at 28.

64. See Hammer, Mergers, Market Power and Competition, supra note 1, at 103-18. The model is a Cournot-type model of quality competition, assuming fixed prices and a form of quality competition that takes place exclusively along vertical non-price dimensions. The results of the model track the results of the traditional Cournot model of quantity competition. The amount of non-price attributes on the market varies directly with the number of competitors: the higher the number of competitors the higher the level of non-price attributes. Individual and firm-specific profits vary inversely with the number of competitors: the larger the number of competitors the lower the profit levels. See also Hammer, Price and Quality Competition, supra note 19, at 131-32 (contrasting the results of the non-price competition model with the results of the traditional Cournot model).

65. See sources cited supra note 1. The claim that lower costs in concentrated markets are attributable to increases in productive efficiency is not well supported. Economies of scale are associated with hospital size, not market structure. While productive efficiency concerns may motivate some mergers, the relevant factor isolated in this literature is market structure (controlling for differences in hospital size) and the dynamics of non-price competition. 
viewed in terms of producer and consumer surplus. ${ }^{66}$ If there are no corresponding reductions in price and if the non-price attribute has any value to consumers, then reducing the level of the nonprice attribute will decrease consumer surplus. Conversely, in the absence of price concessions, the lower costs associated with decreased non-price competition will increase hospital surplus (profits). In determining the social desirability of mergers, it is necessary to consider both effects by examining the impact of merger on total welfare (the sum of producer and consumer surplus). Much of the confusion in the hospital merger case law can be attributed to the failure of courts and the FTC to explicitly recognize and balance these concurrent and conflicting effects.

\section{B. $F T C$-In re American Medical International, Inc.}

In 1979, the for-profit hospital chain American Medical International ("AMI") acquired French Hospital in San Luis Obispo, giving AMI control of three of the five hospitals in the county. In 1981, the FTC challenged the acquisition under a variety of antitrust theories, seeking divestiture of French Hospital. The Administrative Law Judge (ALJ) ruled against AMI, and AMI appealed to the full Commission. ${ }^{67}$ AMI's brief and Commissioner Calvani's decision provide a thorough examination of the legal and economic issues raised by hospital competition in the Old Regime. AMI challenged the ALJ's determination that the widespread quality and non-price competition characteristic of hospital markets

66. By focusing on hospital profits and consumer surplus, this analysis does not directly consider the effects of merger on physician well-being. Non-price competition can take many different forms. Some forms seek to cultivate physician loyalty and affiliation as a surrogate means of obtaining patients. This article assesses allocative efficiency in terms of the health care consumer's willingness to pay. Under such a standard, non-price investments that generate direct benefits to patients/consumers are extended a higher level of antitrust protection than non-price investments aimed at elements in physician utility functions. Moreover, this analysis is indifferent to whether economic rents go to hospitals or are shared by physicians. If one believed that competition for physicians generated no social value, then the economic cost of certain types of physician-oriented non-price competition may be even greater than suggested by the allocative inefficiency standing alone. $C f$. Richard A. Posner, The Social Cost of Monopoly and Regulation, 83 J. PoL. ECoN. 807, 809-15 (1975) (exploring generally how the efforts to obtain and retain monopoly power can constitute part of the social cost of monopoly.).

67. See In re American Med. Int'l, Inc. 104 F.T.C. 1 (1984). 
constituted beneficial forms of economic competition that should be protected by the antitrust laws. ${ }^{68}$

[C] onduct of this kind in the hospital field is not competition in the economic sense because it is not disciplined by an effective price mechanism. Neither doctors, nor hospitals, nor patients weigh the benefits of additional services and equipment against their costs. Such activity thus takes place without regard to existing duplicative facilities in the same locality or anticipated volume of use. ${ }^{69}$

The FTC rejected AMI's claim, reasoning that hospitals actively compete along non-price dimensions and that non-price competition is desirable. ${ }^{70}$ Furthermore, the FTC found that the merger had already generated anticompetitive effects. "AMI's acquisition of French Hospital virtually eliminated the nonprice competition that existed between hospitals in San Luis Obispo." ${ }^{, 11}$ In declaring the acquisition unlawful, the FTC focused almost exclusively upon the effects of merger on consumer surplus. Commissioner Calvani reasoned that non-price competition enhanced consumer surplus. "There is no doubt that consumers in the health care industry benefit substantially from the nonprice competition that exists ...." ${ }^{, 2}$ From that point on, the logic of the opinion is easy to summarize: non-price competition increases consumer surplus, mergers decrease non-price competition, therefore, hospital mergers are undesirable.

[T] he nonprice competition that does exist in the industry responds to consumers' expressions of their wants by providing services valued by physicians and patients, such as expanding the range of choices available to them, stimulating innovation, and developing expertise by hospitals, we conclude that "rivalry" among hospitals along nonprice dimensions constitutes competition in the economic sense that warrants protection by the antitrust laws. ${ }^{73}$

68. Respondents' Brief on Appeal from Initial Decision, In re American Med. Int'l, Inc., 104 F.T.C. 1, 12-13 (1984) (Docket No. 9158).

69. Id. (citations omitted).

70. See In re American Med. Int'l, 104 F.T.C. at 182-85.

71. Id. at 207.

72. Id. at 184

73. Id. at 185. The district court in United States v. Rockford Memorial Corp., 717 F. Supp. 1251 (N.D. Ill. 1989), affd, 898 F.2d 1278 (7th Cir. 1990), also acknowledged the beneficial effects of hospital competition on quality and non-price dimensions: 
The Commission dismissed AMI's claim that non-price competition, undisciplined by an active price mechanism, was undesirable. ${ }^{74}$ The FTC contended that hospital behavior was sufficiently constrained because hospital administrators factored in the costs of the non-price attribute when making their internal decisions. $^{75}$ This analysis, however, runs the danger of missing an important point. Non-price competition may be rational from the individual hospital perspective (the revenues generated exceed the cost of the investment) but irrational from the social perspective (the cost of the investment in the non-price attribute exceeds what informed consumers would be willing to pay if offered a lower quality option at a correspondingly lower price). It is the latter comparison that is economically germane, unless one views nonprice competition simply as a device for transforming producer surplus into consumer surplus. Market failures in the Old Regime distort the economic signaling role of prices. One cannot necessarily infer that because a transaction takes place the cost of providing the non-price amenity reflects what consumers would be willing to pay if given an unbundled option. Competition strictly for marketshares may well lead to decisions that, while individually rational, are socially undesirable. ${ }^{76}$ Not surprisingly, some commentators compare the medical arms race driving hospital non-price competition with the prisoner's dilemma. ${ }^{77}$

For similar reasons, non-price competition such as advertising and quality of care has also intensified, as each hospital desires to offer physicians and patients the latest medical technology and services in an effort to present itself as a full service high quality institution. The hoped-for result of these efforts, of course, is the attraction of quality physicians and more and better paying patients.

Id. (citations to record omitted). The court held that eliminating non-price competition would be one of the anticompetitive temptations of merger. "Through a collusive exercise of market power the hospitals in the relevant market could also eliminate 'quality' competition that has been a major drain on the hospitals' budget." Id. at 1285 .

74. See In re American Med. Int'l, Inc., 104 F.T.C. at 182-83.

75. See id. at 183.

76. Hospitals are concerned with the determinants of hospital-specific demand. Quality investments stimulate hospital-specific demand both by increasing market demand and, more importantly, by diverting demand from other hospitals. The "demand-stealing" effects provide incentives to supply quantities of the non-price attribute that may exceed the level justified by consumer preferences as reflected in the market demand function. See supra note 12 and accompanying text.

77. See generally Joseph M. Jadlow, Hospital Competition and the Prisoner's Dilemma, 25 RIvista Internazionale di SCienze EConomiche e Comerciali 360 (1978). 


\section{District Court Cases}

If $A M I$ can be criticized for its myopic focus on consumer surplus, the district court in Carilion ${ }^{78}$ can be criticized for the opposite failing. The court failed to distinguish the impact of merger on non-price competition from possible productive efficiency gains, holding that mergers decrease costs and that all cost reductions are desirable. ${ }^{79}$ The district court in University Health ${ }^{80}$ was more explicit, contending that reduced competition after the merger would be in the public interest because it would eliminate "unnecessary and wasteful duplication." ${ }^{81}$ The court failed to appreciate the negative impact that reduced non-price competition would have on consumers. The same mistake is frequently made in health care policy circles. Like most errors, it is half-grounded in truth. Mergers lower costs by decreasing the amount of non-price competition, not by improving productive efficiency. The merged hospitals are not providing the same product at a lower cost; rather, the hospitals are supplying a different product at a lower cost, a product with fewer non-price attributes. Failure to recognize this distinction has led courts to ignore the potential loss to consumers-the consumer benefits identified by the Commission in $A M P^{2}$ - and to look favorably on any merger that decreases hospital costs (and correspondingly increases hospital profits).

78. United States v. Carilion Hosp. Sys., 707 F. Supp. 840 (W.D. Va. 1989).

79. Id. at 846; see also Long Island Jewish Med. Ctr., 983 F. Supp 121, 142 (E.D.N.Y. 1997) (tending to classify reductions in cost due to avoiding the duplication of services as unambiguous efficiency gains, rather than reductions in the range of services available to consumers).

80. FTC v. University Health, Inc., 1991-1 Trade Cases (CCH) I 69,400 (S.D. Ga.), rev'd, 938 F.2d 1206 (11th Cir. 1991).

81. Id. at 65,615 . The district court reasoned that non-price competition was undesirable and that the elimination of "unnecessary duplication" was a factor justifying the merger. On appeal, the FTC argued that the hospitals' efforts to eliminate non-price competition was evidence of the merger's likely anticompetitive effect (stating the merger would yield a level of service and non-price amenities that would be lower than the comparable competitive equilibrium). See University Health, 938 F.2d at 1220 n.27. While noting the FTC's position, the appellate court did not attempt to resolve the conflict. See id. Instead, the court reversed the district court's denial of the FTC's preliminary injunction holding that, as a factual matter, the merging hospitals had failed to meet their burden of demonstrating with sufficient evidence the existence of actual efficiencies to justify the merger. See id. at 1223 .

82. Appreciation of the potential benefits of non-price competition is not limited to AMI. See FTC v. Tenet Healthcare Corp., 17 F. Supp. 2d 937, 946 (E.D. Mo. 1998) ("The competition has prompted improved hospital quality and services. To compete within the market, Lucy Lee and DRMC have routinely added new services, recruited high-quality physicians to an area that traditionally would have difficulties attracting physicians, and established rural outreach clinics."), rev'd., 186 F.3d 1045 (8th Cir. 1999). 
The district court in Mercy Health Services ${ }^{89}$ similarly failed to appreciate the detrimental effects of reducing non-price competition. The court provided a caricatured version of the government's argument-reducing the government's concerns over non-price competition to concerns over the remodeling of hospital rooms and the elimination of free consumer give-aways. ${ }^{84}$ The government attempted to portray post-merger reductions in non-price competition as a price increase, rightfully arguing that consumers would be paying higher relative prices. ${ }^{85}$ The court rejected the claim:

The government has not shown that these amenities improve the quality of health care received and it can certainly be argued that they unnecessarily add to health care costs. Further, even if not giving away car seats or failing to remodel can be considered a price increase, the government has not shown these to be significant price increases for purposes of antitrust analysis. ${ }^{86}$

The Mercy Health Services court may or may not be right as a matter of social policy, but one thing is certain: by second-guessing the desirability of non-price competition, the court is substituting its own judgment concerning the proper allocation of social resources for the judgment of the market. As such, the debate over non-price competition is actually a debate over whether hospital competition in the Old Regime is a rational means of allocating health care resources. Unfortunately, most courts engage in this analysis without thoughtful consideration of how such an economic assessment should be carried out or whether such arguments are doctrinally legitimate.

83. United States v. Mercy Health Services, 902 F. Supp. 968 (N.D. Iowa 1995).

84. See id. at 987 .

85. See id. at $986-87$. If one could accurately calculate quality-adjusted prices, then the problems of non-price competition could be conceptually reduced to a problem of price competition. It is simply wrong, however, to conclude that there are no antitrust issues when one observes constant prices in the face of falling quality. Courts in other antitrust contexts have acknowledged the importance of considering quality-adjusted prices. See Roland Mach. Co. v. Dresser Indus., 749 F.2d 380, 395 (7th Gir. 1984) (discussing the potential of exclusive dealing arrangements to produce lower quality-adjusted prices); Little Caesar Enter. v. Smith, 1997-1 Trade Cases (CCH) I 71,817, at 79,755 (E.D. Mich. 1997) (discussing qualityadjusted prices in the context of tied products).

86. Mercy Health Services, 902 F. Supp. at 987. 


\section{Total Welfare Criterion}

In deciding whether courts should entertain arguments concerning the efficacy of competition, it is helpful to understand how non-price competition problems might be resolved as a matter of social policy. A social planner would assess the effects of hospital mergers on total social welfare. A total welfare standard would permit a merger so long as it satisfied the following two criteria: (1) the cost savings gained by reducing non-price competition are greater than the corresponding decrease in consumer surplus; and (2) the net gains in social welfare from reduced non-price competition (if any) outweigh other anticompetitive effects. ${ }^{87}$ The first requirement will be satisfied if the gain to hospitals from restricting non-price competition exceeds the loss to consumers from the reduction in the non-price attribute. ${ }^{88}$ The analysis can be thought of

87. Elsewhere, I have outlined a framework for assessing legislative reforms of the antitrust laws. Desirable reforms should: (1) be targeted at remedying an identifiable market failure; (2) increase total welfare (static efficiency concerns); and (3) not adversely affect the underlying structure and operation of the market (dynamic efficiency concerns). See Hammer, Arrow, Coase and the Changing Structure of the Firm, supra note 16, at 13-14. This Article focuses mainly on the static welfare effects of hospital mergers. Consequently, the considerations isolated in the text-whether the increase in producer profits exceeds the reduction in consumer surplus and whether the net welfare increase outweighs the anticompetitive effects of merger-flesh out the second prong of the three part test. Before sanctioning increases in market power, policymakers would also want to be certain that the merger would not undermine the underlying transition of health care markets to more efficient organizational forms (dynamic efficiency). Some of the dynamic efficiency concerns raised by hospital mergers were addressed supra note 27 (discussion of hospital incentives to eliminate excess capacity), others are addressed infra notes 142-143 and accompanying text (discussion of hospital incentives in Butterworth to forestall the transition from the Old to the Emerging Regime via the Community Commitment Letter).

88. In practice, determining consumer valuation of non-price amenities is a difficult task. A working price mechanism provides a visible benchmark of the minimum amount purchasing consumers are willing to pay for any given service. In the Old Regime, numerous factors dilute the economic content of price signals. Some insight can be gained by recognizing that there are different types of non-price competition. Simplistically, one can think of "actual" quality competition, "perceived" quality competition, and competition for physician affiliation. Competition that fosters investments aimed at improving "actual" quality, defined as investments targeted at well-informed consumers, deserves the most protection. Competition in "perceived" quality, defined as investments targeted at imperfectly informed consumers, is less valuable. Finally, competition strictly for physician loyalty and affiliation, defined as investments aimed at elements in individual physician utility functions, deserves the least amount of protection.

The implications for merger analysis are straightforward. Debate should focus on the social desirability of the specific types of non-price competition that are dominant in a given market. As a theoretical matter, the question is whether consumers value the non-price attribute sufficiently so that they would be willing to independently pay for its costs as an unbundled option. The effects of reduced non-price competition on hospital surplus are potentially easier to quantify. 
in terms of a Kaldor-Hicks compensation problem, ${ }^{89}$ or assessing whether the merger is potentially Pareto superior. ${ }^{90}$ If the net gain is positive and exceeds whatever other anticompetitive effects might be associated with the merger, then the merger increases total welfare and should be permitted.

While economists are quick to reference the total welfare criteria, the standard employed by antitrust courts and scholars is less clear. Judge Bork calls on courts to use a "consumer welfare" standard, ${ }^{91}$ but defines "consumer welfare" in a manner that is identical to the "total welfare" standard described above. ${ }^{92}$ When courts require efficiency gains of mergers to be "passed on" to consumers, they are implicitly using a consumer surplus standard of review. ${ }^{93}$

89. See Richard A. Posner, Economic Analysis of Law 14-17 (5th ed. 1998) (discussing the Kaldor-Hicks concept of efficiency).

90. See CoOTer \& ULEN, supra note 13, at 40-41 (discussing the concept of potential Pareto improvements).

91. See Robert H. Bork, The Antitrust Paradox: A Policy at War with Itself 107-15 (The Free Press 1993) (1978) (defining his concept of consumer welfare).

92. I use the terms total welfare, producer surplus and consumer surplus in the traditional economic sense of partial equilibrium analysis, where consumer surplus represents the difference between the amount consumers would be willing to pay for the product and how much they actually pay, and producer surplus can be equated with producer profits. See, e.g., John R. Morris, International Trade and Antitrust: Comments, 61 U. Cin. L. Rev. 945, 945 n.4 (1993) (noting how antitrust use of "consumer welfare" differs from traditional economic use of the term "consumer surplus"). Unfortunately, substantial confusion surrounds the term "consumer welfare." Consumer welfare has been called "the most abused term in modern antitrust analysis." Joseph F. Brodley, The Economic Goals of Antitrust: Efficiency, Consumer Welfare, and Technological Progress, 62 N.Y.U. L. Rev. 1020, 1032 (1987). Judge Bork's use of "consumer welfare" to mean what economists call "total welfare" (the sum of producer and consumer surplus) has caused those who advocate for what economists would call a "consumer surplus" standard to (re) define their criteria in distributional terms of preventing "wealth transfers." See Robert H. Lande, Wealth Transfers as the Original and Primary Concern of Antitrust: The Efficiency Interpretation Challenged, 34 HASTINGs L.J. 65, 74-77 (1982). Whether antitrust law should be guided by a total welfare or a consumer surplus standard of merger review remains an important legal and policy question. Contrasting consumer surplus and total welfare (as done in this Article) is helpful because it does not mask the distributive implications of the debate.

93. Many courts require efficiency benefits of merger to be "passed on" to consumers. In $A M$, Calvani required the hospitals to establish that the efficiency gains will "necessarily inure to the benefit of consumers." In re American Med. Int'l., Inc., 104 F.T.C. 1, 219 (1984). The district court in Rockford imposed a similar requirement. See United States v. Rockford Mem'l Corp., 717 F. Supp. 1251, 1289 (N.D. Ill. 1989) (“[D]efendants must establish by clear and convincing evidence that the efficiencies provided by the merger produce a significant economic benefit to consumers ...."), affd 898 F.2d 1278 (7th Cir. 1990); see also FTC v. University Health Inc., 938 F.2d 1206, 1223 (11th Cir. 1991) ("[W]e hold that a defendant who seeks to overcome a presumption that a proposed acquisition would substantially lessen competition must demonstrate that the intended acquisition would result in significant economies and that these economies ultimately would benefit competition, and hence, consumers."); FTC v. Cardinal Health, Inc., 12 F. Supp. 2d. 34, 61 (D.D.C. 1998) (evaluating the defendants claim that at least half of the efficiency gains of merger would be passed on to consumers in the form of lower prices); FTC v. Tenet Healthcare Corp., 17 F. Supp. 2d 
More often, it is not possible to tell whether antitrust opinions, even those that invoke "consumer" interests or speak expressly in terms of "consumer welfare," intend to employ a total welfare or a consumer surplus standard to guide their decision making. ${ }^{94}$

937, 948 (E.D. Mo. 1998) ("For example, defendants claim that the merger will increase efficiencies by decreasing operating costs and avoiding capital costs. However, the merged hospital is unlikely to pass these savings on to its consumers absent competitive pressure to lower prices."), rev'd, 186 F.3d 1045 (8th Cir. 1999); United States v. Long Island Jewish Med. Ctr., 983 F. Supp. 121, 147 (E.D.N.Y. 1997) ("[T]he defendants must show that the intended merger itself, rather than any other factor, would result in significant economies and that these economies ultimately would benefit the consumers."); FTC v. Staples, $970 \mathrm{~F}$. Supp. 1066, 1089-90 (D.D.C. 1997) (rejecting defendants argument that two-thirds of the projected efficiencies would be passed on to consumers through lower prices); FTC v. Butterworth Health Corp., 946 F. Supp. 1285, 1301 (W.D. Mich. 1996) ("In sum, the Court is persuaded that the proposed merger would result in significant efficiencies ... and represents savings that would, in view of defendants' nonprofit status and the Community Commitment, invariably be passed on to consumers."); United States v. United Tote Inc., 768 F. Supp. 1064, 1084-85 (D. Del. 1991) (" $[\mathrm{E}]$ ven if the merger resulted in efficiency gains, there are no guarantees that these savings would be passed on to the consuming public."); California v. American Stores Co., 697 F. Supp. 1125, 1133 (C.D. Cal. 1988) ("Moreover, even assuming these efficiency savings do result, the Court is not convinced that defendants will invariably pass these savings on to consumers."). For academic commentary on the "passing on" requirement, see Mark N. Berry, Efficiencies and Horizontal Mergers: In Search of a Defense, 33 San Diego L. Rev. 515, 545-47 (1996); Thomas L. Greaney, Regulating for Efficiency in Health Care Through the Antitrust Laws, 1995 UTAH L. REv. 465, 495; and Robert Pitofsky, Proposals for Revised United States Merger Enforcement in a Global Economy, 81 GEo. L.J. 195, 197-98, 221 (1992). See generally Robert M. Vernail, One Step Forward, One Step Back: How the Pass-On Requirement for Efficiencies Benefits in FTC v. Staples Undermines the Revisions to the Horizontal Merger Guidelines Efficiencies Section, 7 Geo. Mason L. Rev. 133 (1998); Paul L. Yde \& Michael G. Vita, Merger Efficiencies: Reconsidering the "Passing-On" Requirement, 64 ANTITRUST L.J. 735 (1996).

94. The FTC's opinion in In re Hospital Corp. of America, 106 F.T.C. 361 (1985), aff d Hospital Corp. of Am., 807 F.2d 1381 (7th Cir. 1986), and the district court's opinion in Rockford Memorial were both appealed to the Seventh Circuit and decided in opinions authored by Judge Richard Posner. Judge Posner's academic writings embrace a total welfare or wealth maximization standard. See Richard A. Posner, Legal Reasoning from the Top Down and from the Bottom Up: The Question of Unenumerated Constitutional Rights, 59 U. CHI. L. Rkv. 433 (1992) [hereinafter Posner, Unenumerated Constitutional Rights] (stating that "judges should interpret the antitrust statutes to make them conform to the dictates of wealth maximization”); see also Richard A. Posner, Antitrust Law: An Economic Perspective 8-22 (1976) (discussing the goals of antitrust law). Posner acknowledges that Bork's use of "consumer welfare" is simply code language for total welfare. Posner, Unenumerated Constitutional Rights, supra, at 434 ('Bork called his theory 'consumer welfare maximization,' but that is just a reassuring term for wealth maximization.") (footnote omitted). The inferences to be drawn from Posner's judicial opinions, however, are less clear. According to Judge Posner, "the economic concept of competition, rather than any desire to preserve rivals as such, is the lodestar that shall guide the contemporary application of antitrust laws, not excluding the Clayton Act." Hospital Corp., 807 F.2d at 1386. In explaining the "economic" approach, Posner focuses upon the impact of the merger on consumers. "So it was prudent for the Commission, rather than resting on the very strict merger decisions of the $1960 \mathrm{~s}$, to inquire into the probability of harm to consumers." Id. (emphasis added). Similarly, in Rockford Memorial, Posner maintained that "the current understanding of section 7 is that it forbids mergers that are likely to "hurt consumers, as by making it easier for the firms in the market to collude ...'" United States v. Rockford Mem'l Corp., 898 F.2d 1278, 1282-83 (7th Cir. 1990) 
This ambiguity is unfortunate because a consumer surplus standard and a total welfare standard can produce different results. Table One-"Welfare Classification of Mergers" outlines six categories of mergers, classified by the merger's effect on consumer surplus, producer surplus and total welfare. It is assumed that a merger's net welfare effect must be either positive or negative from each constituent perspective.

TABLE ONE

Welfare Classification of Mergers ${ }^{95}$

Categories of Mergers

\begin{tabular}{|l|c|c|c|c|c|c|}
\hline & 1 & 2 & 3 & 4 & 5 & 6 \\
\hline Total Welfare & + & + & + & - & - & - \\
\hline Consumer Surplus & + & - & + & - & + & - \\
\hline Product Surplus & + & + & - & + & - & - \\
\hline
\end{tabular}

A total welfare criterion permits any merger in which the net effect is positive (Categories 1-3). Given that the parties must agree to the merger, it can be assumed that only mergers that increase producer surplus will take place (Categories 1, 2, and 4). The total welfare and the consumer surplus standard allow Category 1 mergers

(quoting Hospital Corp., 807 F.2d at 1386) (emphasis added). On their face, these passages tend to suggest a consumer surplus standard of review-antitrust law prohibits restraints of trade that have the effect of reducing consumer surplus-unless one defines "consumers" in these opinions not as the actual purchasers of the hospital's services, but rather as representing all members of society, i.e. as shareholders of the for-profit corporation in Hospital Corp. or as all members of the "community" represented by the nonprofit hospital boards in Rockford Memorial. See, e.g., Bork supra note 91, at 110 ("Those who continue to buy after a monopoly is formed pay more for the same output, and that shifts income from them to the monopoly and its owners, who are also consumers. This is not dead-weight loss due to restriction of output but merely a shift in income between two classes of consumers.").

95. Table One separates mergers into six possible categories, depending upon the effect a merger has on consumer surplus, producer surplus (profits), and total welfare. Total welfare is simply the sum of producer and consumer surplus. For example, a Category 1 merger increases both producer surplus (profits) and consumer surplus. This type of merger makes all stakeholders better off. The merger most feared by the antitrust law is where the decrease in consumer surplus is greater than the increase in producer surplus, leading to reduction in total welfare (a Category 4 merger).

A total welfare antitrust standard would prohibit all mergers that decrease total welfare (Categories 4-6) and would permit mergers that increase total welfare (Categories 1-3). A consumer surplus antitrust standard would prohibit mergers that decrease consumer surplus (Categories 2, 4, and 6) and would permit any mergers that increased consumer surplus (Categories 1, 3, and 5). The total welfare and the consumer surplus standard will differ in Category 2 mergers, where there is a clear reduction in consumer surplus, but a more than off-setting increase in producer surplus, leading to an increase in total welfare. 
in which all stakeholders are made better off. Both standards will disallow mergers in which the harm to consumers exceeds the benefit to producers (Category 4 mergers where the net effect on total welfare is negative). The total welfare standard and the consumer surplus standard, however, differ in Category 2 mergers. Category 2 mergers involve a clear reduction in consumer surplus, but while consumers are worse off, their loss is more than offset by the gain to producers. ${ }^{96}$ From a total welfare perspective, these mergers should be permitted. This is the scenario potentially raised by hospital mergers that reduce non-price competition in the Old Regime.

Analysis of non-price competition under a total welfare standard is an example of intra-economic balancing. The cost of merger (in the form of reduced consumer surplus) is balanced against the benefit of merger (cost savings that would flow to the hospitals from reduced non-price expenditures). A finding that the gains to hospitals exceed the loss to consumers is a necessary but not sufficient condition for merger approval. The net gains in terms of reduced non-price competition must then be balanced against other potential anticompetitive effects, including the effect of merger on health care prices. ${ }^{97}$ There is no theoretical or empirical reason to believe that all or even most hospital mergers in the Old Regime are, in fact, efficiency-enhancing Category. 2 mergers. This is an open question. It is likely that in some circumstances the reduced non-price competition will create a net reduction in total welfare (i.e., a Category 4 merger).

If a court were to employ a consumer surplus standard, its analysis would be substantially different. Any reduction in consumer surplus would be a sufficient reason to oppose the merger. Under a consumer surplus standard, courts would examine whether the

96. Category 2 also includes some mergers envisioned by Oliver Williamson in his advocacy of an efficiency defense. See Williamson, supra note 49, at 21-23. Productive efficiency gains of merger may produce cost savings that favorably shift the average cost curve. These gains may exceed the dead weight loss attributed to a reduction in allocative efficiency. See $i d$. Under such circumstances, total welfare is increased, but there is no guarantee that consumer surplus will be similarly enhanced. A total welfare standard would permit any merger where the productive efficiency gain exceeds the dead weight loss. A consumer surplus standard would prohibit mergers unless the increase in productive efficiency was so large, it produced lower post-merger prices. A consumer surplus standard, or a requirement that the benefits of merger be "passed on" to consumers will prohibit many mergers that would otherwise be welfare enhancing.

97. Conceptually, it is similar to analysis already undertaken in assessing alleged productive efficiency gains of merger. The primary difference is that courts are assessing and balancing increases in allocative efficiency (by sanctioning market structures that better calibrate non-price attributes with the theoretical consumer's willingness to pay) rather than productive efficiency. 
hospitals' cost savings from reduced non-price competition would be "passed on" to consumers, potentially in the form of lower prices. If cost savings were not "passed on," then even a merger that increased total welfare would be rejected. From this perspective, debates about the price effects of hospital merger are often arguments over the distribution of the benefits from reduced nonprice competition, making it difficult to separate discussions of price and non-price effects in merger cases.

\section{The Presumption That Market Power Yields Higher Hospital Prices}

The transition from the Old to the Emerging Regime has important implications for hospital price claims. In the Emerging Regime, where third-party payors actively negotiate with hospitals over price, the assumption that market power leads to higher medical prices is generally defensible ${ }^{98}$ and traditional antitrust

98. See Dranove \& Ludwick, supra note 2, at 97 (“[O]ur findings contradict Lynk's conclusion that nonprofit mergers are, on average, associated with lower prices. If anything, we find that nonprofit mergers are associated with higher prices.") (1989 data from California); Keeler et al., supra note 2, at 71 ("We find strong evidence that the nature of hospital competition has shifted so that price plays a much more significant role. In particular, there has been a steady increase in the impact of market concentration on hospital pricing behavior.") (1986-94 data from California); see also David Dranove et al., Price and Concentration in Hospital Markets: The Switch from Patient-Driven to Payor-Driven Competition, 36 J.L. \& Econ. 179, 180 (1993) ("We hypothesize that the shift from patient-driven to payer-driven competition will have two effects on hospital profit margins: it will (1) reduce the margin between prices and costs and (2) increase the degree to which the relationship between margins and concentration conforms with the standard $1 / O$ [industrial organization] paradigm.... [W] e confirm our hypotheses about the effects of the shift to payer-driven competition: that is, margins are falling and increasingly conform with the standard I/O paradigm.") (1983-88 data from California); Glenn A. Melnick et al., The Effects of Market Structure and Bargaining Position on Hospital Prices, 11 J. Health Econ. 217, 229 (1992) (“Our results indicate that prices paid to hospitals in the Blue Cross of California PPO network, after controlling for hospital product differences, are strongly influenced by the competitive structure of the hospital market. Hospitals located in less competitive markets are able to secure higher prices.") (1987 Blue Cross of California per-diem price data for medical/surgical services negotiated with hospitals in their PPO network); James C. Robinson \& Ciaran S. Phibbs, An Evaluation of Medicaid Selective Contracting in California, 8 J. HEALTH EcoN. 437, 453 (1989) ("Hospitals with larger Medi-Cal patient shares and hospitals in structurally competitive local markets reported lower rates of cost inflation over the four years following the 1982 reforms [selective contracting] than did otherwise similar hospitals with smaller Medi-Cal shares and fewer local competitors.") (1982-86 data from California); Jack Zwanziger \& Glenn A. Melnick, The Effects of Hospital Competition and the Medicare PPS Program on Hospital Cost Behavior in California, $7 \mathrm{~J}$. Health Econ. 301, 316 (1988) ("The results of our analysis strongly support the hypothesis that the nature of hospital competition underwent a structural change as a result of the implementation of California's 'pro-competitive' legislation. As expected, hospitals competed on a non-price basis before 1983, and, increasingly, on a price basis after 1983.") 
presumptions about the effects of merger are aligned with the likely economic reality. The relationship between market power and price for hospitals still mired in the Old Regime, however, is potentially very different. In these markets, it is theoretically possible that market power can be associated with lower prices. Courts and the FTC have reacted to this possibility in dramatically different ways. The FTC rejected these claims both as a theoretical matter and because these claims are inconsistent with the second step of the Philadelphia formula. ${ }^{99}$ The district courts in Carilion and Butterworth, on the other hand, accepted the hospitals' price claims as a basis for permitting merger, without necessarily appreciating the full doctrinal ramifications of their decisions. ${ }^{100}$

\section{A. FTC-In re American Medical International, Inc.}

In $A M I$, the hospitals broadly challenged the applicability of the antitrust laws to hospital mergers, arguing that no price competition existed in medical markets. For support, they cited the defining characteristics of the Old Regime: pervasive insurance coverage, fee-for-service systems of reimbursement, the absence of consumer price information, and the role of physicians as agents for patients. ${ }^{101}$ The FTC rejected the hospitals' economic arguments, as well as their legal conclusions. First, while recognizing certain unique aspects of medical markets, the Commission found that these market failures dampened, but did not eliminate, price competition. According to Commissioner Calvani, some degree of hospital price competition "exists among hospitals in various 'attenuated' forms that warrant protection from the antitrust laws." ${ }^{102}$ Second, the FTC cited evidence in the record of actual price competition between the pre-merged hospitals. "The record also documents AMI's acknowledgment that, in the abstract, competition among hospitals constrains their ability to raise rates and that, in practice, price competition between hospitals in San Luis Obispo County did constrain hospital charges." ${ }^{103}$ The Commission

(1980-85 data from California). For a review of some of this literature, see Pautler \& Vita, supra note 1, at 129-32. As indicated in the parentheticals, almost all of these studies examine the effects of reforms in California. These studies are indicative of the likely effects of competition in the Emerging Regime. Not all markets, however, fall into this category.

99. See infra Part IV.A (discussing $A M I$ ).

100. See infra Part IV.B-C (discussing Carilion and Butterworth respectively).

101. See In re American Med. Int'l, Inc., 104 F.T.C. 1 (1984).

102. Id. at 179 .

103. Id. at 180 . 
further held that the merger had the actual effect of decreasing price competition. "AMI's acquisition of French Hospital has already lessened price competition and is likely to continue to lessen price competition, to the extent that any price competition remains." 104

Finally, the Commission held that even if no price competition existed, the antitrust laws would still apply and be strictly enforced. $^{105}$ In essence, AMI was arguing that the absence of traditional forms of price competition created a de facto exception from the antitrust laws for hospital mergers. ${ }^{106}$ Suggesting that the law imposed certain binding constraints on the FTC's decisionmaking ability, Calvani concluded that "it is the role of Congress, not the Commission, to legislate exemptions from the antitrust laws." Here, the Commission implicitly confronted the second step of the Philadelphia formula, the assumption that market power presumptively causes undesirable (and hence illegal) anticompetitive effects and deferred to Congress, illustrating the channeling function that these rules can serve.

AMI rephrased its price claims in terms of a direct attack on Philadelphia's market-share rule:

AMI's contention [is] that Judge Barnes erred in relying on indices based on market shares in determining the competitive effects of the acquisition. AMI argues that the traditional presumption that a substantial increase in market concentration or in a firm's market share results in a lessening of competition, as enunciated by the Supreme Court in United States $v$. Philadelphia National Bank ... is not applicable in the health care industry because the economic assumptions on which this presumption is based (which AMI argues are present in "manufacturing and related industries") are not present in this industry. ${ }^{108}$

The FTC rejected the argument citing both its earlier findings of the presence of actual price competition in the San Luis Obispo market and noting numerous incidents in which courts had applied market-share presumptions in non-manufacturing contexts, including, ironically, the banking industry at issue in Philadelphia. ${ }^{109}$

\footnotetext{
104. Id. at 202.

105. See id. at 180 .

106. See id.

107. Id.

108. Id. at 198.

109. See id. at 198-99.
} 
Consistent with the analysis in $A M I$, the FTC in $H C A^{110}$ and the district court in Rockford Memorial' ${ }^{11}$ proceeded to invoke the Philadelphia framework and to evaluate the competitive effects of hospital mergers without paying significant attention to the nonmanufacturing setting in which the mergers were taking place. ${ }^{112}$

\section{B. Carilion District Court}

The pricing analysis of the district court in Carilion ${ }^{119}$ contrasts sharply with the FTC's analysis in AMI. Carilion involved the merger of two nonprofit hospitals in Roanoke, Virginia. In assessing the likely competitive effects of the merger, the court came to a surprising conclusion. The court held that hospital market power leads to lower medical prices. " court also finds that as a general mule hospital rates are lower, the fewer the number of hospitals in the area."115 This statement turns upside down the traditional assumption that economic concentration produces higher prices. Based in part on this finding, the court concluded that the merger did not violate the antitrust laws. ${ }^{116}$

In all likelihood, the Carilion court's statement reflected a misunderstanding of the expert testimony presented at trial. The hospitals' expert witness, Dr. Eisenstadt, did not testify that there was a negative correlation between market power and hospital prices, but rather, that there was no statistically significant relationship between economic concentration and price levels. ${ }^{17}$ It was this more limited claim, and not the district court's finding, that the defendants briefed on appeal. "The hospitals' economic expert, Dr. Eisenstadt, described studies he had performed in connection with other nonprofit hospital mergers showing no evidence of

110. In re Hospital Corp. of Am., 106 F.T.C. 361 (1982).

11. United States v. Rockford Mem'l Corp., 717 F. Supp. 1251 (1989).

112. See id. at 1279 (citing Philadelphia and examining the competitive effects of merger in light of market-share presumptions); Hospital Corp., 106 F.T.C. at 488 (calculating marketshares and citing Philadelphia to support the inference of anticompetivive effects from high levels of economic concentration).

113. United States v. Carilion Health Sys., 707 F. Supp. 840, 846-49 (W.D.Va. 1989).

114. See id. at 846 .

115. Id. (emphasis added).

116. See id. at 849 .

117. This more limited version of the testimony is consistent with the finding of Eisenstadt's contemporaneous research. See David M. Eisenstadt \& Robert T. Masson, Price Effects from Recent Nonprofit Hospital Mergers (presented at the American Public Health Association Meeting, Chicago, Ill.) (Oct. 23, 1989). 
higher prices in areas with fewer hospitals." ${ }^{118}$ The brief continues, "there was no significant relationship between the rate of price increases in areas which experienced mergers and in comparable areas that did not experience mergers ...."

Many aspects of the Carilion opinion suggest that the court was predisposed to approve the merger regardless of its likely price effects. The court rejected the jury's finding that the relevant geographic market was limited to the Roanoke Valley, in favor of the court's own more broadly defined market-directly undermining the Philadelphia market-share presumption. ${ }^{120}$ The court accepted the hospitals asserted efficiencies, failing to distinguish those lower costs that might be attributed to increased productive efficiency from those associated with decreased non-price competition. ${ }^{121}$ Finally, the court determined that the nonprofit status of the hospitals and their pro-competitive intentions were factors weighing in favor of the merger's legality. ${ }^{122}$ While careful not to cross the line and engage in express forms of extra-economic balancing, the court made it clear that it did not believe that market power in the nonprofit hospital industry represented a serious social concern, regardless of the predictions of traditional antitrust and economic theory.

\section{Butterworth District Court}

The most comprehensive challenge to the presumption that market power leads to higher prices was mounted by the defendant hospitals in Butterworth. ${ }^{123}$ Significantly, the district court found that the merger of the two largest hospitals in Grand Rapids,

118. Brief for Appellees at 30, United States v. Carilion Health Sys., 892 F.2d 1042 (4th Cir. 1989) (No. 89-2625).

119. Id. at 31. From an econometrics perspective, the Eisenstadt study is subject to criticisms pertaining to the construction of the non-merger control clusters, the short time period allowed for post-merger price effects to develop, and the failure to consider possible effects of merger on non-price attributes of hospital services. See Hammer, Mergers, Market Power \& Competition, supra note 1, at 16-20. Aside from these criticisms, the study is generally consistent with this Article's characterizations of hospital competition in the Old Regime. Price competition simply does not play a dominant role and market structure does not appear to make a systematic difference in non-quality-adjusted prices.

120. See Carilion, 707 F. Supp. at 848 .

121. See id. at $845-46$.

122. See id. at 849 .

123. FTC v. Butterworth, 946 F. Supp. 1285, 1295-1301 (W.D. Mich. 1996), affd without op., 121 F.3d 708, reported in full, 1997-2 Trade Cas. (CCH) I 71,863 (6th Cir. 1997). 
Michigan would produce market power. ${ }^{124}$ Moreover, the court rejected arguments that such market power could not be exercised, finding substantial barriers to entry. ${ }^{125}$ In terms of the decision tree in Figure One, this placed the court on the third node (balancing). Recognizing that market power both existed and could be exercised, the only option left to the parties was to mount a direct challenge to the second step of the Philadelphia formula and to persuade the court to balance the potential benefits of merger against any anticompetitive effects. The court entertained and was ultimately persuaded by these arguments. In reaching its conclusion, the court examined empirical evidence challenging the relationship between market power and price, ${ }^{126}$ the hospitals' Community Commitment Letter declaring the defendants' intent not to use their market power for anticompetitive ends, ${ }^{127}$ and the community-based nature of the hospitals' board. ${ }^{128}$ Each of these contentions will be considered in turn.

1. Market Power and Price-Economic Testimony_-“[D]efendants contend that empirical proof does not support the presumption that high concentration of market power among nonprofit hospitals results in price increases." ${ }^{29}$ Dr. William Lynk testified as the hospitals' expert. The court favorably reported the findings of Lynk's examination of the pricing practices of for-profit and nonprofit California hospitals. "'Relative to for-profit hospitals, private nonprofit hospitals in this sample have a significantly lower association between higher market shares and higher prices, and on balance increased nonprofit market share is associated with lower, not higher, prices." " ${ }^{130}$ Based upon this and other related evidence,

124. See id. at 1294 ("Therefore, the Court concludes the FTC has established its prima facie case that the proposed merger would violate $\$ 7$ of the Clayton Act. The FTC has statistically demonstrated that the proposed merger would result in a significant increase in the concentration of power in two relevant markets, and produce an entity controlling an undue percentage share of each of those markets.").

125. See id. at 1298 ("[T]he Court finds that, due to the greater range of services ... available at defendant hospitals, St. Mary's and Metropolitan's ability to compete with the merged entity and defeat a small but significant price increase would be limited, especially for the foreseeable future.").

126. See id. at 1295-96.

127. See id. at 1298.

128. See id. at 1296-97.

129. Id. at 1295 .

130. Id. (quoting William J. Lynk, Nonprofit Hospital Mergers and the Exercise of Market Power, 38 J.L. \& Econ. 437, 459 (1995)). The results of Lynk's 1995 study have been questioned by other researchers. Dranove and Ludwick argue that Lynk's econometrics specification suffers from both a simultaneity and omitted variables bias. See Dranove \& Ludwick, supra note 2, at 88-90. The authors construct a data set similar to the one employed by Lynk, replicate his findings using an econometrics specification similar to his, and then assess the effects of nonprofit status and merger under their own specifications that 
the court concluded that the defendants have demonstrated "good reason to question the applicability of the traditional presumption that a significant increase in market concentration will lead to higher prices in connection with the merger of nonprofit hospitals."

The court's finding is juxtaposed with two other facts in the record. First, the FTC's expert, Dr. Leffler, demonstrated that Lynk's Michigan data also established "a positive correlation between market concentration and profit margins." ${ }^{132}$ In other words, nonprofit hospitals in highly concentrated settings both charged less for their services and yet somehow earned relatively higher "profits." Second, the entities benefiting the most from lower prices in the Grand Rapids market were managed care organizations that had "exercised leverage to obtain discounts." ${ }^{133}$ Indeed, an acknowledged purpose of the merger was to prevent further discounting to managed care entities. "[D]efendants have made no secret of their desire, in the event of merger, to level the managed care organization playing field by establishing standard managed care rates." aged care plans at pre-merger levels." ${ }^{35}$ The price "freeze" was to take place in an environment of falling prices for managed care companies.

Butterworth invites further exploration of the relationship between price and non-price competition in hospital markets. It is misleading to examine price in isolation. Price comparisons are

address the omitted variables and simultaneity problems. See id. at 91-93. Under the newly specified equations, Dranove and Ludwick report that nonprofit status and merger are no longer associated with lower prices, and that, if anything, "nonprofit mergers are associated with higher prices." Id. at 97. Keeler, Melnick and Zwanziger attempt to assess the robustness of Lynk's finding over time. See Keeler et al., supra note 2, at 72 . Lynk employed 1989 data from California. Keeler, Melnick and Zwanziger try to examine the effects of nonprofit status and merger on California hospitals over the 1986 to 1994 period. See id. at 72 . The authors also seek to test whether the role of price and non-price competition changed over the period. The researchers found that a projected merger of two nonprofit hospitals in 1986 would be associated with no significant change in price. See id. at 81 tbl.4. In 1989, the same nonprofit merger would be associated with a $2.8 \%$ increase in price (in contrast with Lynk's estimated $4.1 \%$ price decrease). See id. By 1994, the same nonprofit merger would be associated with a price increase of $7.3 \%$. See id. Lynk responds to these and other criticisms by stressing that many of his critics' 1989 findings are "in the same ballpark" as his earlier findings, Lynk \& Neumann, supra note 2, at 102, and by arguing that his critics give inadequate attention to the potential pricing disparities between for- and nonprofits, which is the central aspect of his claim. See id. at 100-01.

131. Butterworth, 946 F. Supp. at 1295.

132. Id. at 1295 .

133. Id. at 1299 .

134. Id.

135. Id. at 1298. 
meaningful only if the characteristics of the underlying commodity or service are held constant. Low prices, unadjusted for changes in quality and other non-price considerations, are not necessarily more beneficial to consumers. Paying less and getting less may or may not represent a better deal. ${ }^{136}$ This is particularly true in the health care context where non-price considerations such as quality play an important role and where strong evidence exists demonstrating that non-price competition is heavily influenced by changes in market structure. Leffler's finding that hospitals in highly concentrated markets had relatively higher markups highlights the relevance of the interaction between price and non-price competition. ${ }^{137}$ These markups could be higher in the face of lower prices, only if there was a corresponding lower level of hospital expenditures of even greater magnitude. Consequently, the real issue remains whether the trade-off between lower prices and reduced non-price amenities is beneficial to consumers, returning the discussion to the same question addressed in Part III: is non-price competition desirable and should mergers that have as their primary effect reductions in non-price rivaliry be permitted? If Lynk is correct, then the distributional effects of who benefits from reductions in non-price competition may be affected by whether the hospitals are for-profit or nonprofit, but the underlying social policy questions of whether such mergers increase total welfare, and whether private markets, hospital boards, district courts, or legislators should make such allocative decisions remain unanswered.

2. Community Commitment Letter-Next, the court considered the hospital's Community Commitment Letter. ${ }^{138}$ The letter established the basis of a consent decree entered by the court, over the objection of the FTC. ${ }^{139}$ The letter and the decree committed the hospitals to freeze list prices and managed care discounts for a three-year period, and placed a ceiling on future price increases up through the seventh year following merger. ${ }^{140}$ The decree also placed limitations on prospective profit margins, albeit permitting

136. See Richard J. Gilbert \& Steven C. Sunshine, Incorporating Dynamic Efficiency Concerns in Merger Analysis: The Use of Innovation Markets, 63 AnTITRust L.J. 569, 572-73 (1995) ("Even product quality has uncertain consequences for consumer welfare. All consumers may agree that higher quality products are better than lower quality ones. Some consumers, however, may prefer to consume lower quality goods at lower prices than higher quality goods at higher prices.").

137. See Butterworth, 946 F. Supp. at 1295.

138. See id. at 1298 .

139. See id. at 1303 .

140. See id. at 1298. 
quite favorable rates of return. ${ }^{14 l}$ In entering the consent decree, a bargain was struck between the hospitals and the court. The nature of the bargain, however, is subject to different interpretations. The letter can be seen as a Coasian contract in which the hospitals were permitted to merge in order to reduce levels of non-price amenities in exchange for future price concessions. Under this interpretation, the consent decree constitutes a device through which the gains of merger could be shared with other segments of the community. ${ }^{142}$

Alternatively, the letter can be viewed as a tactic by the hospitals to strategically influence the direction of future economic change in the market. Managed care organizations were beginning to penetrate the Grand Rapids market and were successfully obtaining price concessions. If this trend continued, one would anticipate a future in which capital expenditures and investments in nonprice attributes would be increasingly dictated by market forces, as mediated through the aggregate preferences of managed care patients, rather than hospital administrators or elite community boards. In the transition from the Old to the Emerging Regime, hospitals stand to lose not simply in terms of prospective profitability, but also in terms of influence and discretion . in decisionmaking. It may have been rationally within the Grand Rapids hospitals' self-interest to commit to a system of loose, short-term price controls in order to hedge against long-term structural changes in the market. ${ }^{143}$

Whether the Community Commitment Letter should be viewed as a welfare-enhancing Coasian bargain or a self-interested effort to influence the structure of the market depends upon one's underlying assumptions about medical markets and the efficacy of

141. See id.; see also United States v. Long Island Jewish Med. Ctr., 983 F. Supp. 121, 13435 (E.D.N.Y. 1997) (discussing the effects of an agreement between the hospitals and the New York State Attorney General and Department of Health to freeze all hospital list prices for two years, subject to inflationary increases).

142. Assuming that a merger would lead to an increase in total welfare, and assuming that there were low transaction costs to bargaining, one would expect the hospitals to be able to reach an agreement with community stakeholders under which the merger would be permitted and the gains of merger would be divided in some manner between local stakeholders. It is difficult to tell a completely harmonious story in the Grand Rapids case, however, in light of the adverse (and uncompensated) effects of merger on managed care organizations and the opposition of the FTC to the consent decree (an entity ostensibly acting to safeguard the public interest).

143. Market structure is, in part, determined by the strategic decisions of market participants. This highlights the need to be sensitive to dynamic efficiency concerns and the effects of decisions on the prospective structure of the market. For further discussion of these issues, see Hammer, Arrow, Coase and the Changing Structure of the Firm, supra note 16, at $37-40$. 
competition. At the end of the Butterworth opinion, the district court's tone shifts dramatically away from arguments made within an economic paradigm (careful assessments of the effects of market power on price) and toward a sharp critique of markets as an acceptable mechanism for making health care decisions. The words and subsequent actions of the court reflect a strong bias against the defining characteristics of the Emerging Regime. The court characterized managed care discounts as undesirable forms of "cost-shifting," benefiting "only select groups of consumers, not consumers as a whole." ${ }^{144}$ The court proceeded to embrace a professional or expert paradigm instead of a market paradigm as the desired means of allocating health care resources. "In the real world, hospitals are in the business of saving lives, and managed care organizations are in the business of saving dollars."145

Whether markets are in fact capable of making these decisions raises complicated economic and social questions. It is clear, however, that antitrust laws generally assume that markets can make these decisions and expressly favor markets as the preferred means of allocating social resources. ${ }^{146}$ In permitting the Grand Rapids merger, the court failed to acknowledge the importance of this underlying assumption and failed to distinguish those aspects of the Philadelphia presumptions that are rebuttable under existing doctrine from those aspects that are not. ${ }^{147}$ The court essentially

144. Butterworth, 946 F. Supp. at 1300.

145. Id. at 1302.

146. See supra notes 56-61 and accompanying text.

147. It is unfortunate that appellate courts affirmed the controversial district court opinions in Carilion and Butterworth in unpublished opinions. In affirming the district court in Carilion, the Fourth Circuit held that the district court judge's determinations were not clearly erroneous. See United States v. Carilion Health Sys., No.89-2625, 1989 WL 157282 at *2-3 (4th Cir. Nov. 29, 1989) (holding that the district court's definition of the relevant product and geographic market, and the district court's assessment of the effect of the merger on competition were not clearly erroneous). Given the structure of the lower courts opinion and its efforts to couch its decision in terms of an expanded market definition and findings of low entry barriers, this was not an unfair disposition. Rebutting the first step of the Philadelphia formula implicates complicated factual questions. The Sixth Circuit, however, was simply mistaken to view the issues presented on appeal as predominantly ones of fact rather than ones of law. See FTC v. Butterworth Health Corp., 1997-2 Trade Cases I $(\mathrm{CCH}) 71,863,80,063$ (6th Cir. 1997) ("The record presented here does not leave us with a firm conviction that the district court erred in its analysis of the facts."). The only legal issue perceived by the court was the hospital's efficiency defense. "The FTC argues that the district court committed legal error by allowing the hospitals to rebut the FTC's prima facie case with evidence that the merger would give rise to consumer savings." $I d$. at 80,064 . The district court's consideration of econometric testimony, the nonprofit status of the hospitals, the Community Commitment Letter, and the community-based structure of the board, however, goes substantially beyond the efficiency considerations recognized by other circuits. Moreover, while "a direct examination of consumer welfare is an appropriate form of $\S 7$ analysis," id., the Butterworth district court's actions transcend acceptable forms of intra- 
bootstrapped the rebuttability of the first step of the Philadelphia presumption (legitimate inquiries into whether market power exists and whether it can be exercised) into a "frontal assault" on the assumed efficiency of markets generally, an outcome expressly disapproved of by the Court in Professional Engineers. ${ }^{148}$ Moreover, the court failed to consider the effects of the hospitals' merger on possible dynamic efficiency concerns and the future composition of the Grand Rapids market. As a practical matter, the effect of the Butterworth decision will be to further entrench the characteristics of the Old Regime, and to substantially impede the ability of the market to transition to the Emerging Regime, a transition that otherwise not only seemed plausible, but imminent.

3. Nonprofit Community Boards-The third consideration relied upon by the court to justify merger was the community-based nature of the hospitals' board. ${ }^{149}$ Market power can be defined in terms of the discretion that private actors have over price-the cliché that monopolists are "price makers" rather than "price takers." The existence of discretion, however, says little about the manner in which such discretion will be exercised. Traditional economic assumptions suggest that private discretion will be exercised in a manner that maximizes producer profits. Theoretically, that same discretion could be exercised in furtherance of other objectivesmaximization of output, cross-subsidies for underserved segments of the population, making physician stakeholders happy, or maximizing the utility of hospital administrators. The hospitals in Butterworth argued that any discretion created by market power would be controlled by the merged hospital's board and exercised in the interests of the community. "[T] he boards of the merging hospitals are comprised of community business leaders who have a direct stake in maintaining high quality, low cost hospital services." 150 Defendants proceeded to draw an analogy to consumer cooperatives, asserting that any market power possessed by the merging hospitals would be exercised to the benefit of consumers. $^{151}$

economic balancing, and cross the line into forms of extra-economic analysis, which does raise important legal questions.

148. See National Soc'y of Prof'l Eng'ṛs v. United States, 435 U.S. 679, 695 (1978).

149. Butterworth, 946 F. Supp. at 1296-97.

150. Id. at 1296.

151. See id. Other courts have made similar arguments. See United States v. Long Island Jewish Med. Ctr., 983 F. Supp. 121, 145-46 (E.D.N.Y. 1997) (relying upon the nonprofit status of the board and its ability to funnel any hospital profits back to the community); FTC v. Freeman Hosp., 911 F. Supp. 1213, 1222-23 (relying on the community-based structure of the board and making a comparison between the board and consumer cooperatives); United States v. Carilion Health Sys., 707 F. Supp. 840, 849 (W.D. Va. 1989) ('Defendants' 
The legal significance of the community-based structure of a hospital's board depends upon which aspect of the Philadelphia formula is being called into question. Three distinct claims could be made. First, the community-based board could be relevant if one believed that community boards made substantively different (and better) allocative decisions than competitive markets. This challenges the heart of the second step of the Philadelphia formula and the presumed efficiency of competitive markets. Second, the community-based structure of the board may be relevant in determining whether market power can or will be exercised. Here, the claim is not that the board will make substantively different decisions than those dictated by the market, but rather that the board can effectively duplicate competitive market outcomes and resist temptations to abuse market power by raising prices above marginal costs. Finally, the community-based nature of the board may be a factor in determining whether savings from the merger, either in terms of increased productive efficiency or reductions in nonprice competition, will be passed on to consumers. ${ }^{152}$ Here, the community-based nature of the board may affect the distributional effects of merger, which would be relevant under a consumer surplus standard of review.

Under existing doctrine, the first claim runs afoul of the second step of the Philadelphia formula and the Court's admonishment in Professional Engineers. It inappropriately adopts a non-market mechanism for making decisions concerning the allocation of economic resources. The second claim, the assertion that a community board is a relevant factor in proving that acknowledged market power will not be exercised, raises an interesting question. The problem with the argument, however, is that the composition of the board is not a structurally self-enforcing characteristic. An analogy to entry barriers is instructive. Entry arguments seek to demonstrate that any exercise of market power would invite competitive entry, which would foil efforts to raise prices. Entry is an automatic response, arising solely from opportunistic self-interest.

A similar analysis would ask what aspects of a community board would automatically frustrate the exercise of market power by the merged hospital. Butterworth draws a comparison to consumer cooperatives, but a community board is not a consumer cooperative.

boards of directors both include business leaders who can be expected to demand that the institutions use the savings achieved through the merger to reduce hospital charges, which are paid in many cases by employers, either directly or though insurance carriers.").

152. See Carilion, 707 F. Supp. at 846 ("Defendants' boards of directors could be expected to help insure that savings realized from the affiliation will be passed on to consumers."). 
Patients at the hospital have no direct voice in hospital decision making and have no means of challenging the implementation of supracompetitive prices. ${ }^{153}$ In the absence of an effective, selfenforcing mechanism to check the exercise of market power, nonprofit status or the community-based nature of the board should be rejected as a factor capable of demonstrating that post-merger market power will not be exercised. ${ }^{154}$ The district court appears to have sensed these inadequacies and devised the consent decree as a means of formalizing and making enforceable the community board's alleged altruistic instincts. Antitrust law, however, generally dictates competition and not court-ordered price regulation as the appropriate response to private market power. The third claim, that the community board ensures cost savings will be "passed on" to consumers in the form of lower prices, suffers from the same structural and self-policing problems as the second claim. If the community-based board will ensure that cost savings inure to the benefit of consumers, such a result is more by accident than inherent design. ${ }^{155}$

\section{Summary}

What lessons can be drawn from the cases addressing the price effects of hospital mergers? There are a number of possible relationships between price and market power in the Old Regime.

153. The status of some board members as large local employers makes the consumer cooperative analogy more persuasive, but these incentives are derivative and one step removed. Moreover, there are potential conflicts between a board member's ability to vigorously pursue the self-interest of her company and her fiduciary duties to the hospital as a member of the board.

154. See United States v. Rockford Mem'l Corp., 717 F. Supp. 1251, 1287 (N.D. Ill. 1989) (“Accordingly, the court finds that the defendants' 'consumer-aligned' boards and not-forprofit status will not necessarily prevent the defendants from engaging in anti-competitive activity."). The court in Mercy Health Services came to a similar conclusion. "[I]f there is the potential for anticompetitive behavior, there is nothing inherent in the structure of the corporate board or the non-profit status of the hospitals which would operate to stop any anticompetitive behavior." United States v. Mercy Health Services, 902 F. Supp. 968, 989 (N.D. Iowa 1995). Mercy Health Services is a religious, nonprofit, regional hospital chain, rather than a free-standing hospital, but the merger was structured to maintain meaningful local control.

155. It is worth contrasting the deference the court suggests giving community boards with the state action doctrine. Private actors will be extended antitrust immunity if there is a clearly articulated state policy to displace competition with regulation, and the actions of the private parties are actively supervised by the state. See California Retail Liquor Dealers Ass'n v. Midcal Aluminum, 445 U.S. 97, 105 (1980). There is no equivalent of active state supervision for the private hospital boards. 
Market power may decrease hospital prices (the district court's finding in Carilion and the expert testimony in Butterworth), market power may have no statistically significant effect on hospital prices (Eisenstadt's testimony in Carilion and the defendants' argument in $A M I)$, or market power could increase hospital prices (Commissioner Calvani's holding in $A M I$ ). The district court's finding in Carilion and Lynk's testimony in Butterworth are theoretically defensible, but the validity of the contention depends ultimately upon the interaction between price and non-price competition. For mergers to produce lower prices, there must be a substantial reduction in non-price competition, as well as an active mechanism to translate lower hospital costs into lower prices for patients. No such price mechanism exists in the Old Regime for the same reasons that there is no effective price competition in the first place. ${ }^{156}$ If the Carilion court's theory were universally valid, then the Eisenstadt study (and others like it) would have produced a statistically significant negative relationship between market power and price. While Lynk's work points in that direction, most of the evidence in the Old Regime suggests that there is simply no systematic relationship between market power and lower price. Even the district court in Butterworth, which was quite sympathetic to the pro-consumer possibilities of community hospital boards, required the signing of a consent decree to make the hospitals' commitment to lower prices legally binding.

When hospitals are mired in the institutional arrangements of the Old Regime, the most defensible proposition is that price competition is simply not the primary concern. Limited price competition may take place, but it is "attenuated" at best and the effect of economic concentration on hospital price levels unadjusted for non-price differences is generally not statistically significant. Consequently, attention in the Old Regime should focus on the effects of merger and economic concentration on non-price competition, and ultimately upon the social value of the resulting non-price attributes. Even the price-oriented focus of Lynk and Butterworth is implicitly about the ability of nonprofit hospitals to translate the lower costs associated with reduced non-price competition into actual price reductions for consumers.

156. Calvani made essentially this same argument when he determined that various efficiency gains advocated by the hospitals would not inure to the benefit of health care consumers. Even if the merger resulted in lower costs (due to increased productive efficiency), those lower costs would not translate in to lower health care prices. See In re American Medical Int'l, Inc., 104 F.T.C. 1, 219-20 (1984). 


\section{Questioning Traditional Antitrust Presumptions}

As is frequently the case, economic theory postulates a possibly straightforward solution to the problems raised by hospital mergers: courts should balance the effects of mergers on producer and consumer surplus and employ a total welfare standard of merger review. Judges, litigants, and commentators, however, have been slow to recognize the simultaneous and potentially conflicting effects of hospital mergers on the providers and consumers of health care services. As a result, courts have reached conflicting and apparently irreconcilable results. Courts that focus on the potential for mergers to reduce medical expenses tend to mischaracterize these savings as "efficiency" gains and to view mergers favorably, without recognizing that the cost savings come at the price of reductions in consumer surplus. Conversely, courts that focus on the impact of merger on non-price competition and the corresponding negative effects on consumers tend to view mergers unfavorably, either without recognizing the potential gain to hospitals (and society at large) of reduced medical expenses or, if recognizing such cost savings, without giving such savings any legal weight.

Courts have difficulty addressing the problem of non-price competition because it requires questioning the unquestionable. The argument that a reduction in non-price competition is beneficial is a thinly veiled claim that competitive markets fail and that market power may produce a superior distribution of social resources. Phrased as such, the argument seeks to rebut the second step of the Philadelphia formula and borders on mounting a "frontal assault" on the basic policy of the nation's antitrust laws. The claim is not that the merged entity will not posses market power, nor that such market power could not be exercised (recognized arguments rebutting the first step of the Philadelphia formula), but rather that the market power resulting from the merger is desirable. The argument can be viewed as a "second best" argument in favor of increased market power. Second best analysis recognizes that while mergers reduce competition and create market power, the reduced competition may be beneficial, even if it decreases consumer surplus. Not surprisingly, none of the litigants in the hospital merger cases have made this claim expressly, and it is doubtful that contemporary antitrust law would respond sympathetically if they did.

In some respects, the unwillingness of antitrust law to critically examine the economic effects of market power is paradoxical. The 
courts' role in interpreting and enforcing the antitrust laws has changed substantially over the hundred-year history of the Sherman Act. Few other statutes have afforded judges as much discretion in decision making. Still, courts have always been of at least two minds. ${ }^{157}$ One mind contends that the judiciary will not question the underlying economic and policy assumptions of antitrust laws, giving a prominent role to presumptions and categorical rules. The other mind suggests a willingness to examine the economic effects of alleged restraints of trade on a case-by-case basis, focusing upon the actual economic effects of the challenged business conduct. Even a cursory examination of contemporary antitrust jurisprudence reveals that the Court's commitment to categorical rules is, at best, selectively invoked. Moreover, the Court's application of categorical rules is heavily dependent upon how the Court decides to characterize the underlying legal and economic issues. ${ }^{158}$ Growth of rule of reason analysis, increased sensitivity to the consequences of various market failures, and a growing range of acceptable procompetitive justifications establish an important current in antitrust law running directly counter to the rigid application of categorical rules. ${ }^{159}$ The widespread acceptance by the enforcement agencies and the lower courts of an efficiency defense under section 7 of the Clayton Act represents

157. Thomas Arthur goes one step further and draws an analogy between contemporary antitrust doctrine and the multiple personalities in The Three Faces of Eve. See Thomas C. Arthur, Farewell to the Sea of Doubt: Jettisoning the Constitutional Sherman Act, 74 CAL. L. REv 263, 309 (1986). The first face is that of a court faithfully interpreting a congressional statute. The second face is the court as an economic regulatory commission. The third face is of the court as a creator or giver of law. See id. at 309-10.

158. Compare, e.g., United States v. Topco Assocs., Inc., 405 U.S. 596, 608 (1972) (declaring per $s e$ illegal the territorial divisions underlying the efforts of small independent grocers to market their own private label brand), with NCAA v. Board of Regents, 468 U.S. 85, 100-04 (1984) (holding that the NCAA's collectively bargained television contract, which limited the aggregate number of games broadcast and prohibited member schools from independently marketing their own games must be examined under the rule of reason). Compare also Maricopa County Med. Soc., 457 U.S. at 342-55 (holding efforts by physicians to collectively negotiate terms and rates with third-party payors to be a per se illegal price fixing conspiracy), with Broadcast Music, Inc. v. CBS, Inc., 441 U.S. 1, 8-10 (1979) (holding that the joint efforts of composers to negotiate blanket licenses was price fixing only in a "literal" sense and would be evaluated under the rule of reason).

159. Part of this trend can be attributed to the increased role of economics in antitrust decision making, leading the Court to revise its understanding of the law and the persuasive power of its own precedents. "In the area of antitrust law, there is a competing interest, well represented in this Court's decisions, in recognizing and adapting to changed circumstances and the lessons of accumulated experience." State Oil Co. v. Khan, 552 U.S. 3, 20 (1997) (overruling the per se rule against vertical maximum price fixing announced in Albrecht $v$. Herald Co., 390 U.S. 145 (1968)). "Accordingly, this Court has reconsidered its decisions construing the Sherman Act when the theoretical underpinnings of those decisions are called into serious question." Khan, 552 U.S. at 21. 
another important development. The efficiency defense permits the benefits of increased productive efficiency to be balanced against losses in allocative efficiency due to the increased market power. A natural but significant evolutionary step in this process would be to recognize a broader range of welfare-enhancing effects of market power in the face of identifiable market failures.

Any attempt to convince courts to openly question the effects of market power must contend with the pragmatic value that presumptions have in judicial decision making. ${ }^{160}$ Economic principles are useful precisely because they serve as a basis to generalize behavior. Courts are often unwilling to make exceptions to bright line rules. Part of this reluctance stems from the difficulties associated with arriving at definitive conclusions once clear presumptions are abandoned. ${ }^{161}$ The contention that courts should be open to a theoretical and empirical examination of the second step of the Philadelphia formula, however, need not render the underlying presumptions triggered by market-share thresholds meaningless. Concerns associated with the potential intractability of the analysis could be addressed by maintaining a strong presumption of anticompetitive effects (based upon a demonstration of market power) and by imposing a heightened evidentiary standard (clear and convincing evidence) for rebutting that presumption. These standards track the initial restrictions placed on the efficiency defense under the 1984 Merger Guidelines. ${ }^{162}$

The extent to which antitrust presumptions can or should be rebuttable raises difficult questions: are the presumption at issue statutorily mandated?; do courts have the administrative competence to address the underlying economic questions on a case-by-case basis?; and is it the proper institutional role for the judiciary to do so? Traditional doctrinalists, Chicago School law and economics

160. Strict adherence to the presumption that market power leads to anticompetitive effects is not surprising. Judicial decision making is itself an exercise in constrained maximization. Judges make decisions subject to the constraints of the law, their institutional role, and their administrative capabilities. As such, judges must be sensitive to the utility of heuristic guidelines and the "economies" derived from categorical rules.

161. Categorical rules permit courts to avoid "the necessity for an incredibly complicated and prolonged economic investigation into the entire history of the industry involved ... an inquiry so often wholly fruitless when undertaken." Northern Pacific Ry. Co. v. United States, 356 U.S. 1, 5 (1958). Consistently applied rules and presumptions also send clearer signals to the public and business community. See Northwest Wholesale Stationers, Inc. v. Pacific Stationery \& Printing Co., 472 U.S. 284, 289 (1985).

162. See U.S. Dep't of Justice 1984 Merger Guidelines, 4 Trade Reg. I 13,103, $\$ 3.5$ (CCH 1988) ("Some mergers that the Department otherwise might challenge may be reasonably necessary to achieve significant net efficiencies. If the parties to the merger establish by clear and convincing evidence that a merger will achieve such efficiencies, the Department will consider those efficiencies in deciding whether to challenge the merger."). 
advocates and post-Chicago School theorists would give different answers to these questions. In slightly caricatured form, doctrinalists would tend to believe that presumptions in favor of competition and against market power have a statutory basis and that exceptions to such rules should be legislated by Congress and not enacted by the courts. Chicago School theorists temper a belief that antitrust law should be guided by principles of efficiency with a dim view of the administrative capacity of courts. Simple rules based on simple models are desired. Strong and potentially irrebuttable presumptions play an important role in this framework. ${ }^{163}$ Post-Chicago School theorists combine frequently more complicated economic models with an optimistic belief in the administrative capacity and competence of the courts. As a result, they are often more willing to cast aside traditional presumptions and encourage ad hoc problem solving by the courts.

I believe that antitrust law has so long and so thoroughly committed itself to a model of common law adjudication, that arguments raising a statutory bar to economic-based arguments challenging presumptions based upon market power are no longer credible. ${ }^{164}$ Economic efficiency is the touchstone of antitrust analysis and efficiency concerns should lead courts, in appropriate circumstances, to question the effects of market power in the presence of other identifiable market failures. Market failures lie at the core of the problems raised by hospital mergers. When market failures are present, antitrust courts should acknowledge their existence in assessing the competitive effects of merger. These assessments are not always easy. As a result, the presumption debate should ultimately turn on an assessment of the capacity of the courts to administer such a broad-ranging economic inquiry and the comparative institutional wisdom of permitting courts (as opposed to legislative of administrative bodies) to undertake such an analysis. While the underlying economic issues are complicated, they are not intrinsically more complicated than the issues that are confronted already in antitrust rule of reason analysis.

163. Skepticism about the administrative capabilities of the courts leads the efficiencyminded advocates of the Chicago school to reject an efficiency defense in merger cases. See Bork, Antitrust Paradox, supra note 91, at 124-29 (citing the difficulties involved in measuring efficiencies and litigating efficiency claims as a reason for rejecting the defense); Posner, Antitrust LAw, supra note 94, at 112 (citing measuring difficulties as a justification for rejecting an efficiency defense).

164. See Kahn, 552 U.S. at 20-21 ("Thus, the general presumption that legislative changes should be left to Congress has less force with respect to the Sherman Act in light of the accepted view that Congress 'expected the courts to give shape to the statute's broad mandate by drawing on common-law tradition.' ") (citation omitted). 
The hospital merger cases illustrate important limitations in current antitrust doctrine. What is called for is either a renewed respect for the role of rigid presumptions in antitrust law and a corresponding deference to the legislature (with acknowledged costs in terms of the type one errors associated with such categorical rules) or the development of a more complete framework that would permit judicial resolution of challenges to the second step of the Philadelphia formula by expressly balancing economic arguments in favor of market power against acknowledged anticompetitive effects. Appropriate respect for the administrative utility and implicit channeling function of market-share presumptions could be maintained within a regime of intra-economic balancing outlined in Part II. The tools and methods of modern welfare economics provide a framework in which to litigate and judicially assess the effects of non-price competition in the Old Regime. Maintaining a sharp distinction between forms of intraeconomic analysis and extra-economic analysis creates a workable division of labor between judges and legislators, while permitting a more satisfactory resolution of the issues raised by hospital mergers than has been achieved to date. 
